Article

\title{
Zinc Phthalocyanine Photochemistry by Raman Imaging, Fluorescence Spectroscopy and Femtosecond Spectroscopy in Normal and Cancerous Human Colon Tissues and Single Cells
}

\author{
Beata Brozek-Pluska *, Arkadiusz Jarota, Rafal Kania and Halina Abramczyk (D) \\ Laboratory of Laser Molecular Spectroscopy, Institute of Applied Radiation Chemistry, \\ Lodz University of Technology, Wroblewskiego 15, 93-590 Lodz, Poland; arkadiusz.jarota@p.lodz.pl (A.J.); \\ rafal_kania_1@yahoo.pl (R.K.); halina.abramczyk@p.lodz.pl (H.A.) \\ * Correspondence: beata.brozek-pluska@p.lodz.pl
}

Academic Editor: Rui Fausto

Received: 4 May 2020; Accepted: 9 June 2020; Published: 10 June 2020

\begin{abstract}
Photodynamic therapy is a clinically approved alternative method for cancer treatment in which a combination of nontoxic drugs known as photosensitizers and oxygen is used. Despite intensive investigations and encouraging results, zinc phthalocyanines (ZnPcs) have not yet been approved as photosensitizers for clinical use. Label-free Raman imaging of nonfixed and unstained normal and cancerous colon human tissues and normal human CCD18-Co and cancerous CaCo-2 cell lines, without and after adding $\mathrm{ZnPcS}_{4}$ photosensitizer, was analyzed. The biochemical composition of normal and cancerous colon tissues and colon cells without and after adding $\mathrm{ZnPcS}_{4}$ at the subcellular level was determined. Analyzing the fluorescence/Raman signals of $\mathrm{ZnPcS}_{4}$, we found that in normal human colon tissue samples, in contrast to cancerous ones, there is a lower affinity to $\mathrm{ZnPcS}_{4}$ phthalocyanine. Moreover, a higher concentration in cancerous tissue was concomitant with a blue shift of the maximum peak position specific for the photosensitizer from 691-695 nm to $689 \mathrm{~nm}$. Simultaneously for both types of samples, the signal was observed in the monomer region, confirming the excellent properties of $\mathrm{ZnPcS}_{4}$ for photo therapy (PDT). For colon cell experiments with a lower concentration of $\mathrm{ZnPcS}_{4}$ photosensitizer, $\mathrm{c}=1 \times 10^{-6} \mathrm{M}$, the phthalocyanine was localized in mitochondria/lipid structures; for a higher concentration, $\mathrm{c}=9 \times 10^{-6} \mathrm{M}$, localization inside the nucleus was predominant. Based on time-resolved experiments, we found that $\mathrm{ZnPcS}_{4}$ in the presence of biological interfaces features longer excited-state lifetime photosensitizers compared to the aqueous solution and bare $\mathrm{ZnPcS}_{4}$ film on $\mathrm{CaF}_{2}$ substrate, which is beneficial for application in PDT.
\end{abstract}

Keywords: colon cancer; Raman imaging; Raman spectroscopy; photosensitizer; photochemistry

\section{Introduction}

Phthalocyanines are important photosensitizers in medical photo diagnostic and photo therapy (PDD, PDT). The unique physical and chemical properties of phthalocyanines, such as their similarity in structure to the biological molecules (chlorophyll, hemoglobin), diversity in chemical structure (central atoms, substituents), near-infrared absorption, high excitation coefficients (typically $>10^{5} \mathrm{~L} \mathrm{~mol}^{-1} \mathrm{~cm}^{-1}$ ), and intrinsic capability to self-assemble, have increased interest in this group of compounds for many years and are crucial for their applications in medicine [1-20].

Every year, the World Health Organization reports thousands of new cases of cancer and around 10 million cancer deaths. Colorectal cancer is the top-ranking cancer, with a ca. $60 \%$ mortality rate worldwide. Colectomy, chemotherapy, and radiotherapy are the primary therapeutic methods. 
However, the chemotherapeutic drug-based treatment of colon cancer is challenging due to the high metastatic potential of cancerous human colon cells and drug toxicity. This is why all new diagnostics and treatment protocols_-designed for early-stage cancer detection and the programming of cancer cells' destruction-are so promising in the fight against this deadly disease.

PDT is an alternative to chemotherapy and chemoradiotherapy. To be brief, PDT involves the combination of light and a photosensitizer. Both factors are harmless in and of themselves, but when combined with oxygen they produce lethal cytotoxic agents, such as singlet oxygen, that destroy cancer cells. It has been proven that the presence of diamagnetic atoms in the phthalocyanine complex, such as zinc (II), aluminum (III), gallium (III), and silicon, results in high triplet quantum yields $\left(\Phi_{\mathrm{T}}>0.4\right)$ and long triplet lifetimes $\left(\tau_{\mathrm{T}}>100 \mu \mathrm{s}\right)$ [21]. Both of these parameters, $\Phi_{\mathrm{T}}$ and $\tau_{\mathrm{T}}$, effectively influence the efficiency of singlet oxygen generation [21]. Zinc phthalocyanines (ZnPcs) have additional advantageous characteristics such as high chemical and photochemical stability, and excitation at wavelengths greater than $630 \mathrm{~nm}$, resulting in deep tissue penetration, and low dark toxicity $[22,23]$. The relatively poor solubility of ZnPcs can be overcome by introducing peripheral and non-peripheral substituents in the Pc framework. Another important disadvantage of Pcs, including $\mathrm{ZnPcs}$, is their intrinsic capability to self-assemble, which effectively reduces the capacity for singlet oxygen production. The photochemical activity is exclusively related to the monomer species [24,25]. Aggregates not only decrease the photoactivity of the Pcs, but also limit access to the neoplastic cells, affecting the bioavailability [26]. This is why additional studies to design new soluble compounds are still necessary. A higher affinity of Pcs to the cancer cells can be obtained due to the specific structure of membranes of cells, e.g., a high content of low-density lipoprotein receptors, which enhances the uptake of photosensitizers [27].

One of the most important factors in PDT is selectivity towards diseased tissue, as only those cells that are simultaneously exposed to the photosensitizer, light, and oxygen are subject to the cytotoxic effect. The selectivity of PDT can be obtained in different ways: by preferential uptake of the photosensitizer by the diseased tissue or by the ability to confine the activation of the photosensitizer by restricting the illumination to a specific tissue region. In general, PDT should allow for the selective destruction of cancers, leaving normal tissue intact.

To date, only a few phthalocyanines have been approved for clinical use or have reached the stage

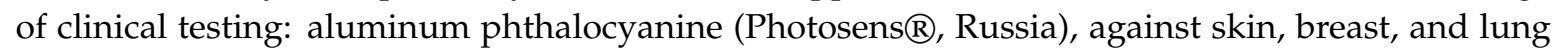
malignancies and cancers of the gastrointestinal tract; and silicon Pc (Pc4®, USA), for the sterilization of blood components against human colon, breast, and ovarian cancers, and gliomas. Zinc phthalocyanine (CGP55847) has undergone clinical trials (phase I/II in Switzerland) against squamous cell carcinomas of the upper aerodigestive tract.

Raman spectroscopy and imaging are well known as sensitive, nondestructive, and highly structured methods that allow for the simultaneous characterization of the biological tissue samples and their interactions with drugs, including photosensitizers, with minimal impact. It has been shown that Raman spectroscopy and imaging have great potential in cancer identification for many human organs (brain [28-31], breast [32-37], esophageal [38,39], stomach [40], salivary gland [41], cervical [42], and colon [43-45]) with high sensitivity and specificity. Simultaneously promising results in Pcs characterization, including their aggregation and selective accumulation, crucial for effective PDT, have been obtained by using Raman spectroscopy and imaging [46-50]. It has also been shown that Raman spectroscopy and imaging can determine effective light doses for PDT, which are safe for noncancerous human tissues surrounding tumor masses and also sufficient to destroy cancer cells [51].

Mechanisms of energy dissipation in biological samples, including systems containing photosensitizers, can be determined by femtosecond spectroscopy. It has been shown that the photochemistry mechanisms observed for normal and cancerous human tissues are different and characterized by long-timescale relaxation processes typical of cancer cells [52,53]. The excited-state lifetime of zinc tetrasulphonated phthalocyanine $\left(\mathrm{ZnPcS}_{4}\right)$ in pure water was found to be fast $(<80 \mathrm{ps})$ due to the formation of aggregates. On the contrary, in micelles the electronic relaxation appears to be 
longer than $1 \mathrm{~ns}$. The elongation of the lifetime in micelles is advantageous for PDT because $\mathrm{ZnPcS}_{4}$ has more time to transfer electronic energy from its triplet state to the triplet state of $\mathrm{O}_{2}$, which leads to an increase in the quantum yield of singlet oxygen formation [54].

Despite phthalocyanines having been studied for many years by experimental and theoretical methods, some problems remain to be solved, including selective accumulation in biological systems and interactions with cells and tissues.

In this paper, we will focus on the photochemical properties of $\mathrm{ZnPcS}_{4}$ and the interactions of $\mathrm{ZnPcS}_{4}$ with normal and cancerous human colon cells and tissues.

\section{Experimental Methods}

\subsection{Phthalocyanine Synthesis}

Zinc tetrasulphonated phthalocyanine was synthesized according to Griffiths and co-workers' method [52]. In this method, dry 4-sulphophthalic anhydride, urea, ammonium chloride, ammonium molybdate, boric acid, and anhydrous aluminum chloride are introduced to sulfolane, slowly heated, and kept for a few hours at a high temperature. The excess of sulfolane is removed and the residue is dissolved in hot water. Finally, a chromatographically pure dye is obtained.

\subsection{Sample Preparation}

Tissue samples were collected during routine surgery. The nonfixed, fresh samples were used to prepare $16 \mu \mathrm{m}$ sections. Specimens of the tissue from the tumor mass and the tissue from the safety margin outside of the tumor mass were prepared for Raman analysis by placing the samples on $\mathrm{CaF}_{2}$ windows. Adjacent sections were used for the typical histological analysis. All tissue procedures were conducted under a protocol approved by the institutional Bioethical Committee at the Medical University of Lodz, Poland (RNN/323/17/KE/17/10/2017). Written informed consent was obtained from all patients. Details of the sample preparation and the research methodology were given in our previous papers [32,50-52]. There are 30 patients in our database.

\subsection{Cell Culture}

CCD-18Co (CRL-1459) cell line was purchased from ATCC (American Type Culture Collection) and cultured using ATCC-formulated Eagle's Minimum Essential Medium (catalog No. 30-2003). To make the complete growth medium, fetal bovine serum was added to a final concentration of $10 \%$. Every 2-3 days, a new medium was used. The CaCo-2 cell line was also purchased from ATCC and cultured according to the ATCC protocols. To make the complete growth medium base on Eagle's Minimum Essential Medium, we added a fetal bovine serum to a final concentration of $20 \%$. The medium was renewed once or twice a week. For all results presented in this manuscript, we recorded the Raman spectra and imaging for paraformaldehyde-fixed cells. The procedure for fixed cells was as follows: cells were seeded onto $\mathrm{CaF}_{2}$ windows $(25 \times 1 \mathrm{~mm})$ at a low density of $10^{3} \mathrm{cells} / \mathrm{cm}^{3}$. After $24 \mathrm{~h}$ incubation on the $\mathrm{CaF}_{2}$ slides of up to half of the samples, $\mathrm{ZnPcS}_{4}-\mathrm{H}_{2} \mathrm{O}$ solution was added for $30 \mathrm{~min}$. After $30 \mathrm{~min}$, the cells were rinsed with phosphate-buffered saline (PBS, Sigma P-5368, $\mathrm{pH} 7.4$ at $25^{\circ} \mathrm{C}, \mathrm{c}=0.01 \mathrm{M}$ ) to remove any residual medium and an excess photosensitizer that did not penetrate inside the cells to be sure that we analyze only the $\mathrm{ZnPcS}_{4}$ accumulated inside the cells, fixed in paraformaldehyde ( $4 \%$ buffered formaldehyde) for $10 \mathrm{~min}$, and washed twice with distilled water. The Raman confocal measurements or femtosecond measurements were made immediately after the preparation of the samples.

\subsection{Raman Spectroscopy and Imaging}

All Raman images and spectra reported in this manuscript were recorded using an Alpha 300 RSA+ confocal microscope (WITec, Ulm, Germany) using a 50- $\mu \mathrm{m}$ core diameter fiber, an Ultra-High-Throughput Spectrometer and CCD Camera Andor Newton DU970NUVB- 353 operating 
in standard mode with $1600 \times 200$ pixels at $-60^{\circ} \mathrm{C}$ with full vertical binning. A 532-nm excitation line - the second harmonic of the Nd:YAG laser-was focused on the sample through $40 \times$ dry objective (NA of 0.60 ) for tissue measurements or 40x water dipping objective (NA of 1.0) for cell measurements. The average laser excitation power was $10 \mathrm{~mW}$, with an integration time of $0.5 \mathrm{~s}$ for Raman measurements for the high-frequency region, of $1.0 \mathrm{~s}$ for the low-frequency region, and of $0.1 \mathrm{~s}$ for fluorescence experiments. An edge filter was used to remove the Rayleigh scattered light. A piezoelectric table was used to record Raman images. Spectra were collected at one acquisition per pixel and 1200 lines/mm diffraction grating. The cosmic rays were removed from each Raman spectrum (model: filter size: 2, dynamic factor: 10) and for the smoothing procedure the Savitzky-Golay method was also implemented (model: order: 4 , derivative: 0 ). Data acquisition and processing were performed using WITec Project Plus. All imaging data were analyzed using the Cluster Analysis (CA) method. Briefly, CA allows for grouping a set of objects (vibrational spectra in our studies) that are similar to each other (in vibrational features in our case). CA was performed using WITec Project Plus software with the Centroid model and the k-means algorithm (each cluster was represented by a single mean vector). Normalization of the data was performed using the Origin software normalization model, divided by norm.

\subsection{Chemical Compounds for Fluorescence Measurements}

Fluorescence measurements were performed using the alpha 300 RSA+ confocal Raman microscope (WITec, Ulm, Germany) described above. Hoechst 33342 (catalog No. B2261, Sigma Life Science, USA) and Red Oil-O (catalog No. O0625, Sigma-Aldrich, MO, USA) were used to visualize cells' substructures without any additional purification.

\subsection{Femtosecond Spectroscopy}

Transient absorption (TA) measurements were performed using a femtosecond laser setup based on a Ti:sapphire oscillator (Tsunami, Spectra-Physics, $82 \mathrm{MHz}, 800 \mathrm{~nm}$, pulse duration < $100 \mathrm{fs}$ ), pumped by a diode laser (Millennia Pro, Spectra-Physics, $532 \mathrm{~nm}, 5 \mathrm{~W}$ ). The femtosecond pulses from the oscillator were used to seed the regenerative amplifier (Spitfire ACE, Spectra-Physics, $1 \mathrm{kHz}$, output power: $4 \mathrm{~W}$ ). The output from the amplifier pumped two optical parametric amplifiers (OPA, Topas Prime, Light Conversion). The outputs from OPAs were directly used in pump-probe experiments. The transient absorption signal $\triangle \mathrm{A}$ was detected by the photodiode (Thorlabs, DET10A) using lock-in detection (Stanford Research, SR830). The pulse duration was determined to be $150 \mathrm{fs}$ in the sample position, as measured by the cross-correlation between the pump and probe pulses in a sample position. The pump and probe pulse energies in TA experiments were set to $\sim 200 \mathrm{~nJ}$ and $15 \mathrm{~nJ}$, respectively.

\subsection{UV-VIS Spectroscopy}

Absorption spectra were recorded with a resolution of $0.5 \mathrm{~nm}$ using a Perkin Elmer Lambda 750 spectrophotometer.

\section{Results and Discussion}

In this section, we present the Raman spectroscopy and imaging results for cancerous and normal (noncancerous) human colon tissues from the same patient. Before we formulate general conclusions that may be useful in clinical diagnostics and treatment, we provide data for the patient denoted as $\mathrm{ZK}$ in our database, to discuss the most important observations regarding the chemical composition of normal and cancerous colon tissues without and after adding $\mathrm{ZnPcS}_{4}$ photosensitizer. We present typical Raman spectra based on the thousands of spectra recorded in our measurements. We focus on the vibrational features typical to human colon cells, normal CCD18-Co, and cancerous CaCo-2 without and after adding the $\mathrm{ZnPcS}_{4}$ photosensitizer. 


\subsection{Absorption Spectra}

Figure 1 shows the absorption spectra of aqueous $\mathrm{ZnPcS}_{4}$ solutions for the photosensitizer concentrations of $\mathrm{c}=1 \times 10^{-4} \mathrm{M}$ (used in our further experiments with human colon tissues), $\mathrm{c}=1 \times 10^{-5}$, and $1 \times 10^{-6} \mathrm{M}$ (used in our further experiments with human colon cell lines).

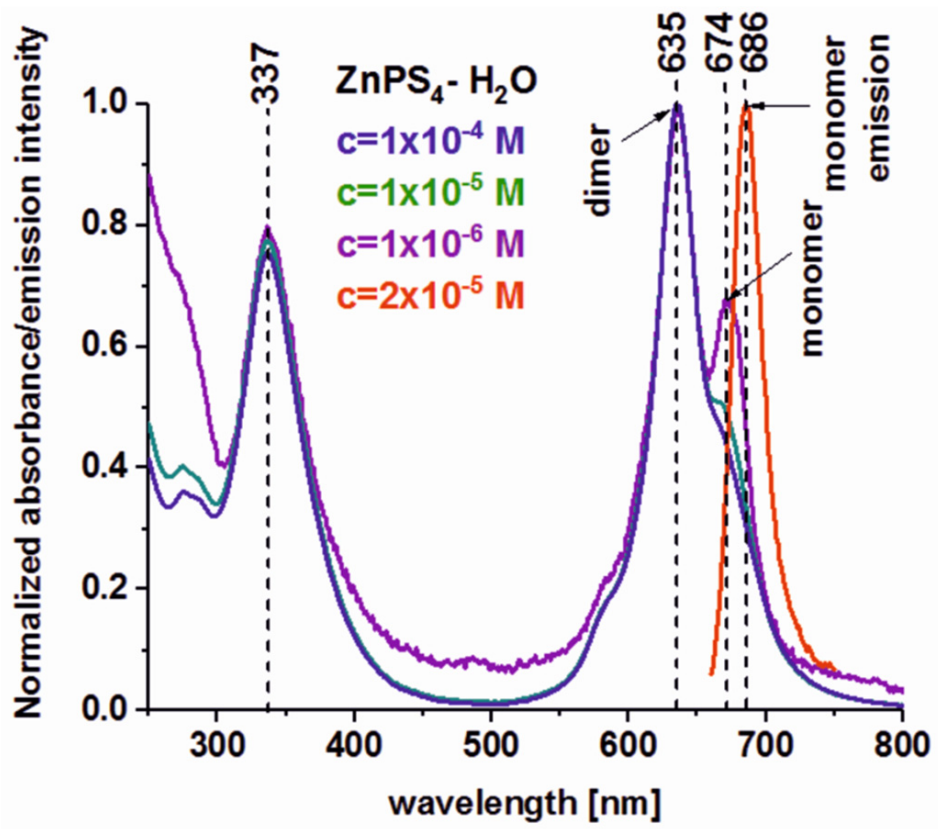

Figure 1. Absorption spectra of aqueous $\mathrm{ZnPcS}_{4}$ solutions for the photosensitizer concentrations of $\mathrm{c}=1 \times 10^{-4}, 1 \times 10^{-5}$, and $1 \times 10^{-6} \mathrm{M}$. Fluorescence spectrum of $\mathrm{ZnPcS}_{4}\left(\mathrm{c}=2 \times 10^{-5} \mathrm{M}\right)$ is also shown.

The spectra shown in Figure 1 comprise two characteristic strong and broad electronic bands: the Soret band $\left(\mathrm{S}_{0} \rightarrow \mathrm{S}_{2}, \pi \rightarrow \pi^{*}\right)$ in the near UV and the $\mathrm{Q}$ band $\left(\mathrm{S}_{0} \rightarrow \mathrm{S}_{1}, \pi \rightarrow \pi^{*}\right)$ on the red side of the spectrum with maxima at ca. 337, 635, and $674 \mathrm{~nm}$ [55].

From a practical point of view and considering the medical applications of phthalocyanines, the most important is an analysis of the $\mathrm{Q}$ band, which provides information about the photosensitizer aggregation. One can see from Figure 1 that the $Q$ band has a complex structure. The band at $635 \mathrm{~nm}$ should be assigned to the dimer and vibrational progression of monomer, while the band at $674 \mathrm{~nm}$ should be assigned to the monomer of $\mathrm{ZnPcS}_{4}$. The aggregation of phthalocyanines plays a crucial role in PDT applications because only monomeric forms effectively generate reactive oxygen species (ROS), constituting the basis of PDT [24,25]. One can also see from Figure 1 that, in the concentration range used in our further experiments, the dimerization of $\mathrm{ZnPcS}_{4}-\mathrm{H}_{2} \mathrm{O}$, even for the concentration $\mathrm{c}=1 \times 10^{-6} \mathrm{M}$, is not negligible. Fortunately, it has been proven that in a human body the dimerization for the aqueous solution of $\mathrm{ZnPcS}_{4}$ has definitely shifted in favor of the monomer [49], which promotes the effectiveness of PDT treatment.

Figure 2 presents the absorption spectra of aqueous $\mathrm{ZnPcS}_{4}$ solution $\left(\mathrm{c}=1 \times 10^{-4} \mathrm{M}\right)$ and $\mathrm{ZnPcS}_{4}-\mathrm{H}_{2} \mathrm{O}$ in the form of a thin film on human colon tissue substrates from normal and cancerous tissues of the same patient, $\mathrm{ZK}$.

One can see from Figure 2 that, in contrast to the solutions, the absorption spectra on biological substrates for normal and cancerous human colon tissues are very broad. These spectra are structureless in the $\mathrm{Q}$ band region, characteristic of the absorption of monomers, dimers, and higher-order aggregates. 


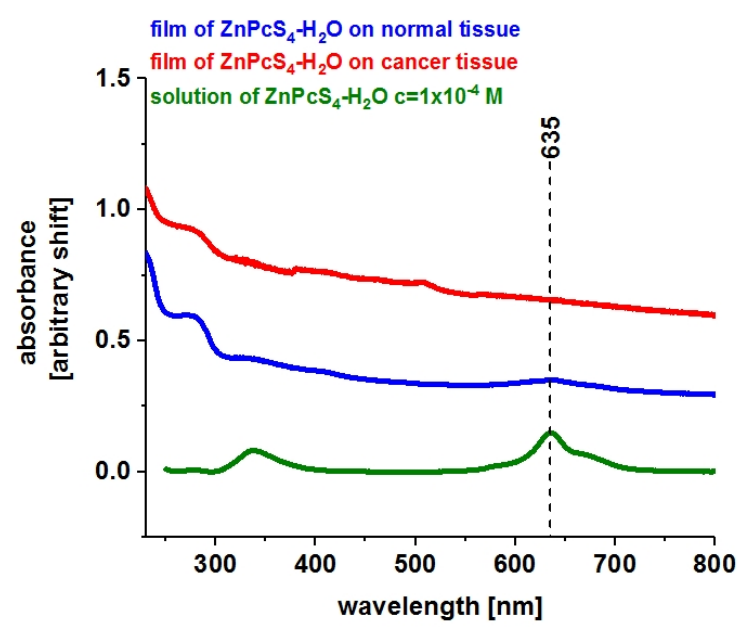

Figure 2. Absorption spectra of $\mathrm{ZnPcS}_{4}$ in a form of a thin film produced on normal and cancerous human colon tissue substrates $\left(\mathrm{V}=20 \mu \mathrm{L}, \mathrm{c}=1 \times 10^{-4} \mathrm{M}\right)$ and in aqueous solution $\left(\mathrm{c}=1 \times 10^{-4} \mathrm{M}\right)$.

\subsection{Human Colon Tissue Without $\mathrm{ZnPcS}_{4}$}

Figure 3 presents the microscopy image, Raman image constructed by CA method, Raman images of all clusters identified by CA, Raman spectra typical of all clusters, and average Raman spectra for cancerous human colon tissue at $532 \mathrm{~nm}$ (for no resonant conditions).
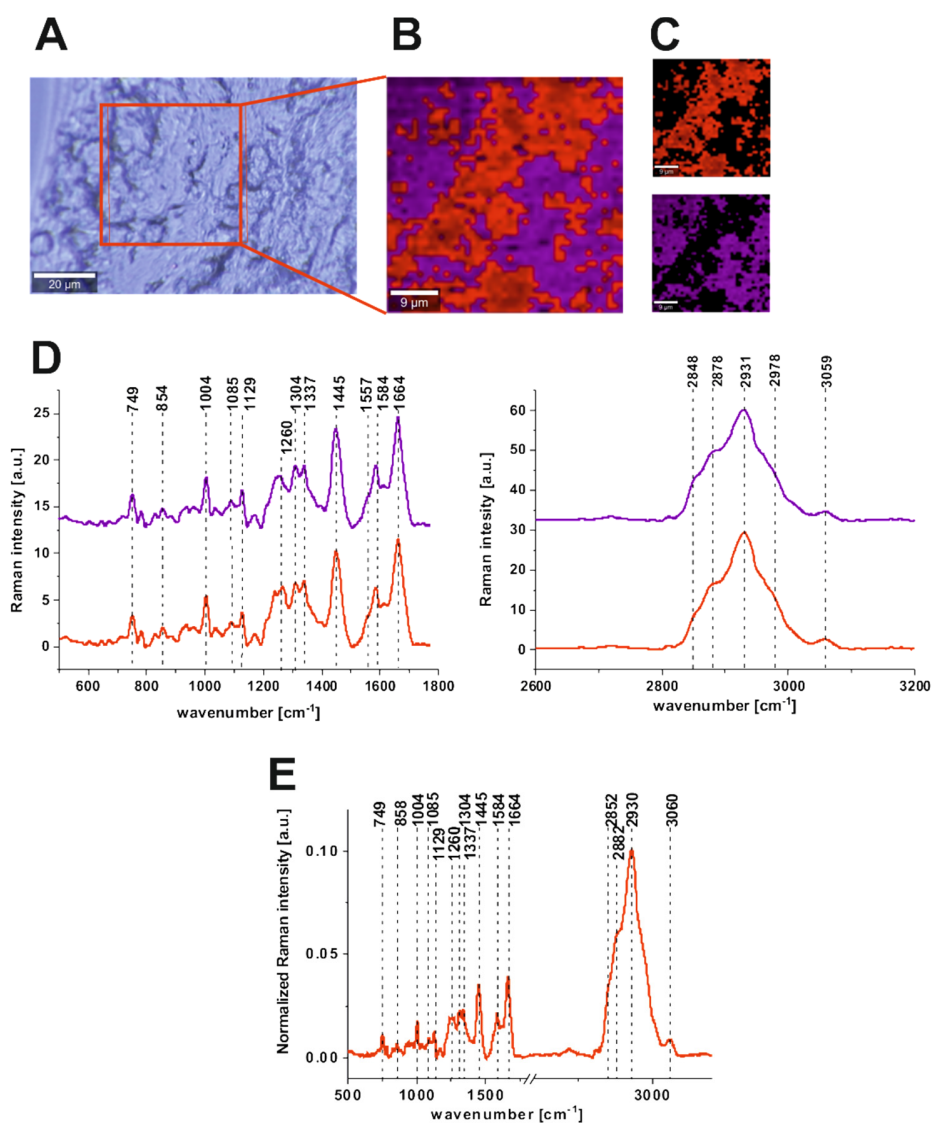

Figure 3. The microscopy image (A), Raman image constructed by Cluster Analysis (CA) method (B), Raman images of all clusters identified by CA (C), average Raman spectra typical of all clusters, colors of the spectra correspond to colors of clusters seen in B and C (D), and average (arithmetic mean) Raman spectrum for the entire area of analyzed tissue (E) for the cancerous human colon tissue (patient ZK) at $532 \mathrm{~nm}$. 
Figure 4 presents the same type of data, obtained by using Raman spectroscopy and imaging for the normal colon tissue from the same patient.


Figure 4. The microscopy image (A), Raman image constructed by CA method (B), Raman images of all clusters identified by CA (C), average Raman spectra typical of all clusters, colors of the spectra correspond to colors of clusters seen in B and C (D), and average (arithmetic mean) Raman spectrum for the entire area of analyzed tissue (E) for the normal human colon tissue (patient ZK) at $532 \mathrm{~nm}$.

One can see from Figures 3 and 4 that, using Raman spectroscopy and imaging, we can obtain the complex biochemical characteristics of human colon tissue samples based on well-resolved vibrational spectra. It is well known that cancerogenesis affects cellular metabolism. The presented results confirm that Raman spectra can provide relevant information about that reprograming metabolism in a simple way compared to traditional biochemical protocols, because Raman-based techniques are label-free, relatively fast, and objective.

For the cancerous human colon tissue, we used two clusters in CA because the sample was very homogenous; the clusters differ subtly in Raman intensity (see Figure 3). This was the expected result; because the cancerous tissue sample during the surgery was extracted directly from the center of the cancer mass. For the normal human colon tissue, the third cluster, dedicated to the lipid-rich regions of the sample (blue), was added and, as one can see from Figure 4, characterized by totally different vibrational profiles in the low- and high-frequency regions.

The fingerprint (low-frequency) region of Raman spectra shown in panel D of Figures 3 and 4 provides a lot of information on the chemical composition of biological samples because each Raman peak corresponds to specific functional groups of the tissues' chemical constituents. 
The peak at $749 \mathrm{~cm}^{-1}$ is typically associated with nucleic acids, DNA, tryptophan, and nucleoproteins [56]; the broad peak with two maxima, ca. 829 and $849 \mathrm{~cm}^{-1}$, should be assigned to tyrosine (the Fermi resonance between the first overtone of the aromatic out of plane ring bend and the aromatic breathing fundamental) [57]; the peak at $858 \mathrm{~cm}^{-1}$ is typical of the stretching mode of the phosphate group from phosphorylated tyrosine (partially overlapping with the phosphate group from DNA) [57]; $872 \mathrm{~cm}^{-1}$ and $938 \mathrm{~cm}^{-1}$ are most probably due to single bond stretching vibrations for the amino acids proline and valine and polysaccharides collagen and tryptophan [56]; the sharp peak at $1004 \mathrm{~cm}^{-1}$ is associated with phenylalanine [57]; the peak at $1085 \mathrm{~cm}^{-1}$ is typical of phosphodiester groups in nucleic acids [57,58]; the signal at $1129 \mathrm{~cm}^{-1}$ is characteristic of saturated fatty acids; the band at $1337 \mathrm{~cm}^{-1}$ is typical of $\mathrm{CH}_{3} \mathrm{CH}_{2}$ wagging vibrations of collagen [59]; the band at $1445 \mathrm{~cm}^{-1}$ is typical of lipids and proteins; the peak at $1585 \mathrm{~cm}^{-1}$ is typical of $\mathrm{CN}_{2}$ scissoring and $\mathrm{NH}_{2}$ rock of mitochondria and phosphorylated proteins [57]; and the peak at $1745 \mathrm{~cm}^{-1}$ characterizes the $\mathrm{C}=\mathrm{O}$ group of lipids and lipids esters. The other, high-intensity group of vibrations can be assigned to lipids, fatty acids, and proteins. Moreover, Raman spectra are secondary structure sensitive [41]. Proteins can be characterized using Raman spectra by peaks typical of Amide I ( $\mathrm{C}=\mathrm{O}$ stretch near $\left.1655 \mathrm{~cm}^{-1}\right)$, Amide II ( $\mathrm{N}-\mathrm{H}$ bend $+\mathrm{C}-\mathrm{N}$ stretch near $1557 \mathrm{~cm}^{-1}$, very weak), and Amide III (C-N stretch $+\mathrm{N}-\mathrm{H}$ bend near $1260 \mathrm{~cm}^{-1}$ ) [57,60]. The recorded high-frequency signals originate in the symmetric and antisymmetric stretching vibrations of C-H bonds of lipids, glycogen, proteins, RNA, and DNA. Lipids and fatty acids, including unsaturated fraction, appear at $2848,2875,2882$, and $3009 \mathrm{~cm}^{-1}[32,56,57,60]$. The contribution of proteins, in the high-frequency region, is seen specifically at 2875,2882 , and $2930 \mathrm{~cm}^{-1}[32,56,57,60]$.

Table 1 summarize all our observations.

To summarize, one can see from Figures 3 and 4 that many peaks are observed for both types of human colon tissues, but this does not mean that the biochemical composition of normal and cancerous human colon tissues is the same. Many qualitative and quantitative differences can be found. The difference spectrum (average spectrum typical of normal tissue minus average spectrum typical of cancerous tissue) is presented in Figure 5. One can see from Figure 5 that the biggest differences can be found for DNA/RNA, phenylalanine, collagen, proteins including phosphorylated proteins, and lipids. The positive peaks in Figure 5 confirm the higher content of DNA/RNA, phenylalanine, collagen, proteins, and phosphorylated proteins in cancerous human colon tissue and the higher content of lipids including unsaturated fraction in the normal one (negative peaks).

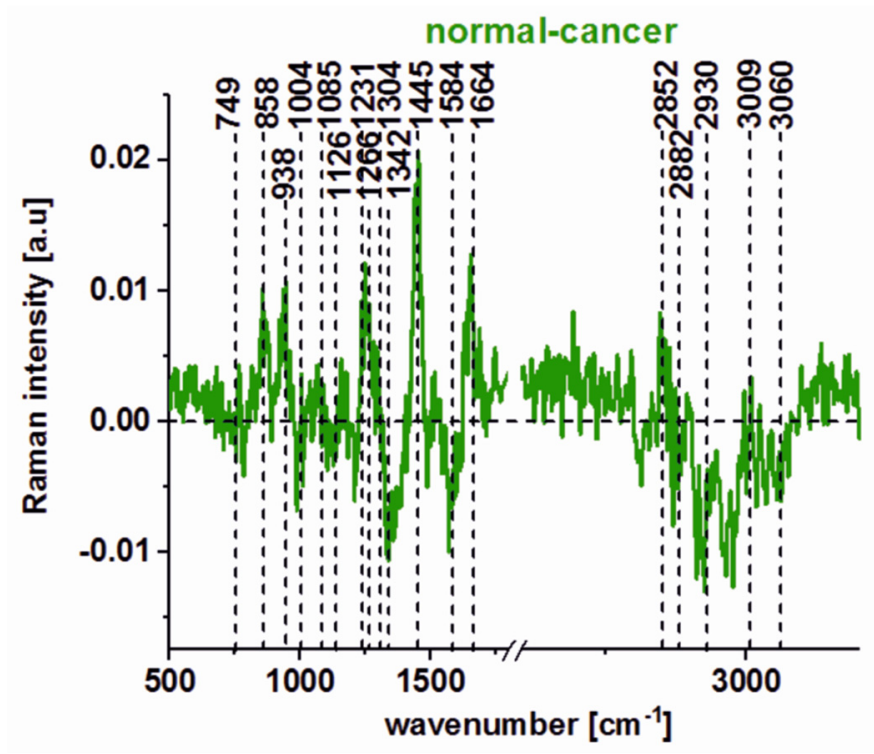

Figure 5. The difference spectrum calculated for normal and cancerous human colon tissues (average spectrum typical of normal tissue minus average spectrum typical of cancerous tissue, based on 4050 Raman single spectra). 
Table 1. The tentative assignments of Raman peaks differentiating the noncancerous and the cancerous tissues of human colon samples. Abbreviations: $\mathrm{C}$-cancerous tissue, $\mathrm{N}$-noncancerous tissue of human colon.

\begin{tabular}{|c|c|c|}
\hline Wavenumber $\left[\mathrm{cm}^{-1}\right]$ & Tentative Assignments & Type of Human Colon Tissue \\
\hline 749 & $\begin{array}{l}\text { nucleic acids, DNA, tryptophan, and } \\
\text { nucleoproteins }\end{array}$ & $C \uparrow$ \\
\hline $829 / 849$ & tyrosine & $\mathrm{N} \uparrow$ \\
\hline 858 & stretching mode of the phosphate group & $\mathrm{N} \uparrow$ \\
\hline $872 / 938$ & $\begin{array}{l}\text { stretching vibrations for the amino acids } \\
\text { proline and valine and polysaccharides }\end{array}$ & $\mathrm{N} \uparrow$ \\
\hline 1004 & phenylalanine & $\mathrm{C} \uparrow$ \\
\hline 1085 & phosphodiester groups in nucleic acids & $\mathrm{C} \uparrow$ \\
\hline 1129 & saturated fatty acids & $C \uparrow$ \\
\hline 1260 & Amide III (C-N stretch $+\mathrm{N}-\mathrm{H}$ bend $)$ & $\mathrm{N} \uparrow$ \\
\hline 1337 & $\mathrm{CH}_{3} \mathrm{CH}_{2}$ wagging vibrations of collagen & $\mathrm{C} \uparrow$ \\
\hline 1445 & lipids and proteins & $\mathrm{N} \uparrow$ \\
\hline 1557 & Amide II (N-H bend + C-N stretch) & $C \uparrow$ \\
\hline 1585 & $\begin{array}{l}\mathrm{CN}_{2} \text { scissoring and } \mathrm{NH}_{2} \text { rock of } \\
\text { mitochondria and phosphorylated proteins }\end{array}$ & $C \uparrow$ \\
\hline 1655 & Amide I ( $\mathrm{C}=\mathrm{O}$ stretch $)$ & $\mathrm{N} \uparrow$ \\
\hline 1745 & $\mathrm{C}=\mathrm{O}$ group of lipids and lipids esters. & $\mathrm{N} \uparrow$ \\
\hline 2848,3009 & $\begin{array}{l}\text { C-H bonds of lipids, glycogen, proteins, } \\
\text { RNA, and DNA. }\end{array}$ & $\mathrm{N} \uparrow$ \\
\hline 2931 & Proteins & $C \uparrow$ \\
\hline
\end{tabular}

\subsection{Human Colon Tissue After Adding $\mathrm{ZnPcS}_{4}$}

The same analysis was performed for human colon tissue samples after adding the $\mathrm{ZnPcS}_{4}$ photosensitizer (the concentration of the aqueous solution was $1 \times 10^{-4} \mathrm{M}$, the volume used was $20 \mu \mathrm{L}$, and the analyzed area was the same as for the tissue without the photosensitizer). Figure 6 presents the microscopy image, Raman image constructed by CA method, and average Raman spectra typical for all clusters for cancerous human colon tissue in the low- and high-frequency ranges and in the range typical of $\mathrm{ZnPCS}_{4}$ fluorescence.

One can see from Figure 6 (panel D) that, after adding $\mathrm{ZnPcS}_{4}$, using Raman spectroscopy and imaging is still possible to obtain complex information about the chemical composition of human colon cancer tissue. Moreover, together with the Raman spectra typical of human cancer tissue, the fluorescence spectra of $\mathrm{ZnPcS}_{4}$ can be recorded (Figure 6C) to give information on the localization, concentration, and aggregation of the photosensitizer and its interactions with constituents of the tissue. As the $\pi$-stacked aggregates do not show fluorescence since the relevant electronic transition is forbidden [61], the observed signal arises from $\mathrm{ZnPcS}_{4}$ monomers or non-cofacial aggregates.

Similar to the sample without $\mathrm{ZnPcS}_{4}$, the spectra for the two clusters are very much alike, which once again confirms the homogeneity of the pathological tissue, removed directly from the tumor mass. From Figure $6 \mathrm{C}$, one can see that the concentration of the $\mathrm{ZnPcS}_{4}$ photosensitizer is also very similar in both clusters as the fluorescence intensity is comparable. The fitting procedure confirmed that the maximum of the fluorescence band of $\mathrm{ZnPcS}_{4}$ photosensitizer is observed for $4302 \mathrm{~cm}^{-1}$ ( $689 \mathrm{~nm}$ for $532 \mathrm{~nm}$ excitation wavelength). 

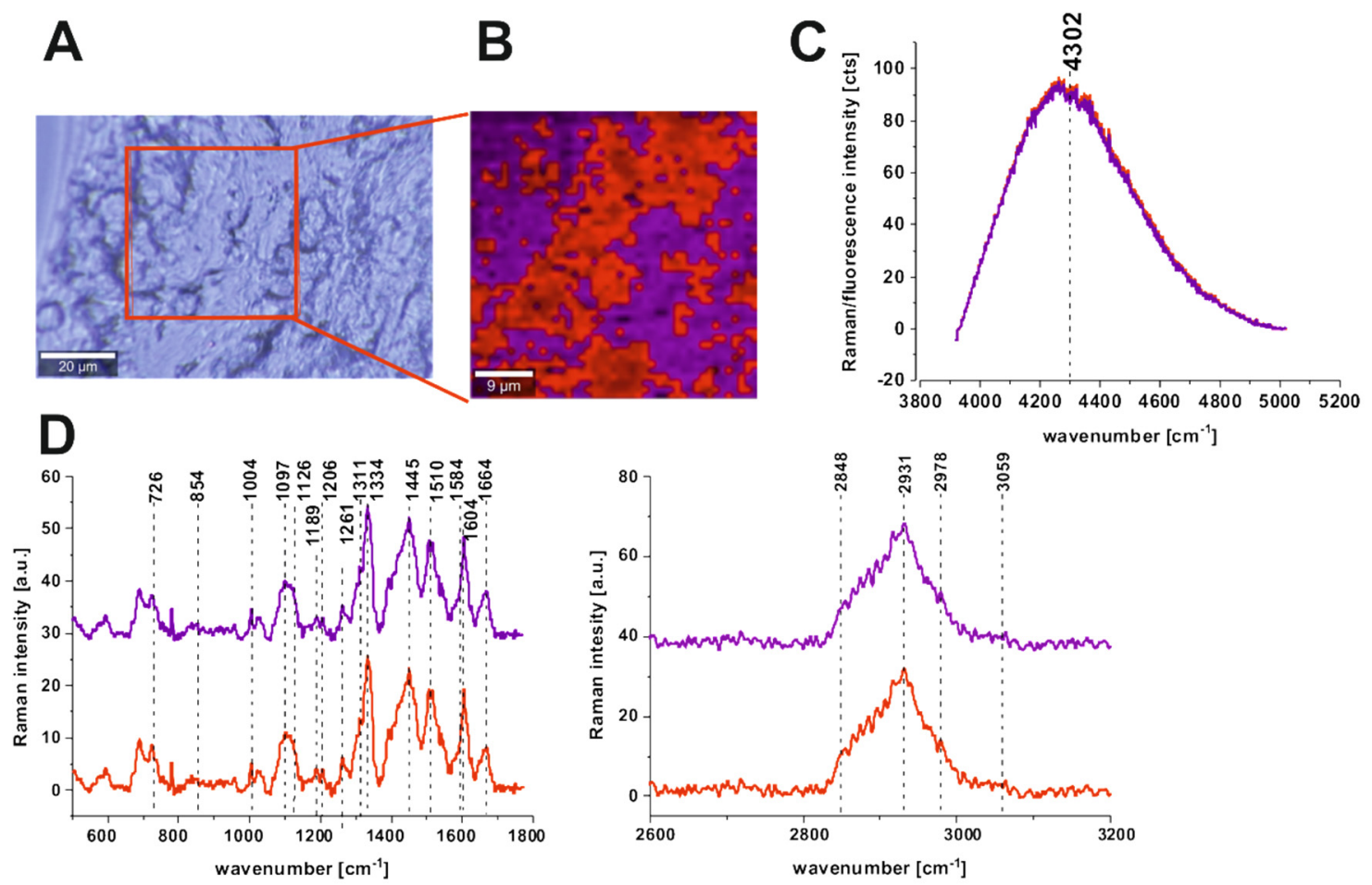

Figure 6. Microscopy image (A), Raman image constructed by CA method (B), Raman/fluorescence spectra in the range typical of $\mathrm{ZnPcS}_{4}$ phthalocyanine fluorescence (C) and average Raman spectra for all clusters, for low- and high-frequency ranges for cancerous human colon tissue after adding $\mathrm{ZnPcS}_{4}$ phthalocyanine (patient ZK) at $532 \mathrm{~nm}($ D).

Figure 7 presents the results obtained for normal colon tissue.

One can see from Figures 6 and 7 that, for the normal tissue sample, the Raman signal typical of $\mathrm{ZnPcS}_{4}$ fluorescence is lower than for cancerous tissue and differentiated in terms of the maximum band position (Figures $6 \mathrm{C}$ and $7 \mathrm{C}$ ). The maximum peak positions typical of phthalocyanine fluorescence observed for the normal colon tissue are $4330 \mathrm{~cm}^{-1}$ (691 nm for $532 \mathrm{~nm}$ excitation wavelength), $4369 \mathrm{~cm}^{-1}$ (693 nm for $532 \mathrm{~nm}$ excitation wavelength), and $4422 \mathrm{~cm}^{-1}$ (695 nm for $532 \mathrm{~nm}$ excitation wavelength). This confirms that, for normal human colon samples, the red shift of the maximum peak position compared to the cancerous tissue ( $689 \mathrm{~nm}$ for $532 \mathrm{~nm}$ excitation wavelength) is observed. Moreover, this effect is accompanied by a decrease in the fluorescence intensity, which suggests a lower concentration of the photosensitizer. The lowest concentration for normal human colon tissue was observed for the lipid-rich region. Moreover, adding $\mathrm{ZnPcS}_{4}$ phthalocyanine does not disrupt the Raman peaks of chemical constituents typical of normal human colon tissue (Figure 7D).

To summarize, for normal human colon tissue samples in contrast to cancerous ones, we observed a lower affinity to $\mathrm{ZnPcS}_{4}$ phthalocyanine (lower Raman/fluorescence signals typical of $\mathrm{ZnPcS}_{4}$ ). The higher concentration in cancerous tissue was concomitant with the blue-shift of the maximum peak position of the photosensitizer (689 $\mathrm{nm}$ for cancerous tissue and $691-695 \mathrm{~nm}$ for normal tissue), but, simultaneously for both types of samples, the signal was observed in the monomer region, confirming the excellent properties of $\mathrm{ZnPcS}_{4}$ for PDT [39,62]. 

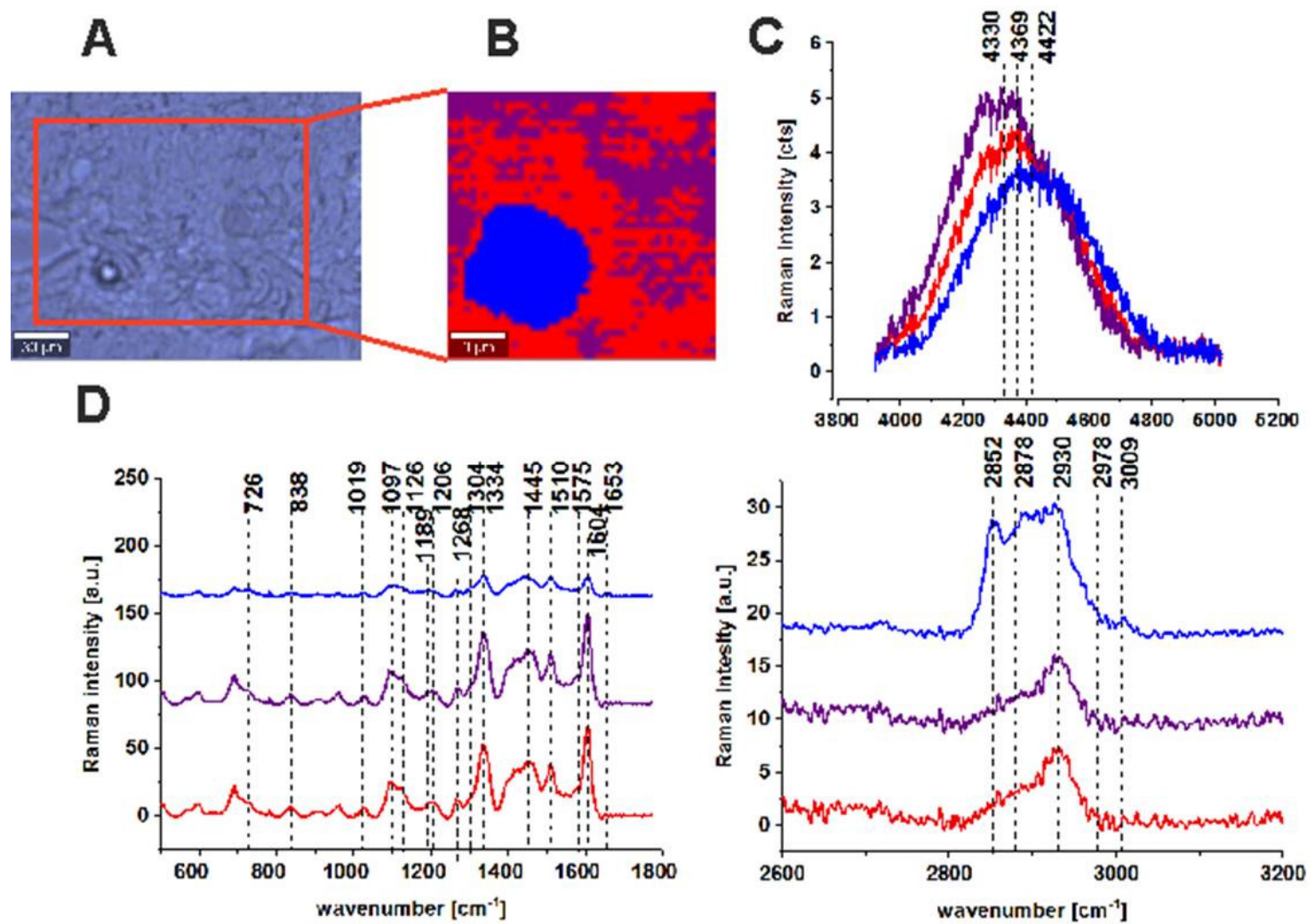

Figure 7. Microscopy image (A), Raman image constructed by CA method (B), Raman/fluorescence spectra in the range typical of $\mathrm{ZnPCS}_{4}$ phthalocyanine fluorescence $(\mathrm{C})$ and average Raman spectra for all clusters, for low- and high-frequency ranges for normal human colon tissue after adding $\mathrm{ZnPcS}_{4}$ phthalocyanine (patient ZK) at $532 \mathrm{~nm}($ D).

\subsection{Human Colon Cells Without $\mathrm{ZnPcS}_{4}$}

An analogous analysis was made for single cells of the human colon. We performed CA to visualize and analyze vibrational features for all substructures of human cells: the nucleus (red), mitochondria (magenta), lipid-rich regions (blue and orange), membrane (light gray), and cytoplasm (green) in low- and high-frequency regions. Figure 8 presents results obtained for cancer human colon cell line CaCo-2: the microscopy image, Raman image constructed based on CA method, Raman images of all clusters identified by CA, Raman spectra typical of all clusters for the low-frequency and high-frequency regions, Raman clusters typical of lipid-rich structures, and nucleus and fluorescence imaging after cell staining using Hoechst 33342 to visualize the nucleus and Red Oil-O to visualize lipid-rich regions (including lipid droplets) for $\mathrm{CaCo}-2$ human cancer cells; the colors of the spectra correspond to the colors of the clusters.

To compare the results for normal and cancerous cells, we performed the same analysis for CCD-18Co normal human colon cells.

Figure 9 presents the microscopy image, Raman image constructed based on CA method, Raman images of all clusters identified by CA, Raman spectra typical of all clusters for low- and high-frequency regions, Raman clusters typical of lipid-rich structures and nucleus, and fluorescence staining obtained using Hoechst 33342 to visualize the nucleus and Red Oil-O to visualize lipid-rich regions, including lipid droplets for CCD18-Co normal human colon cells. The colors of the spectra correspond to the colors of the clusters. 

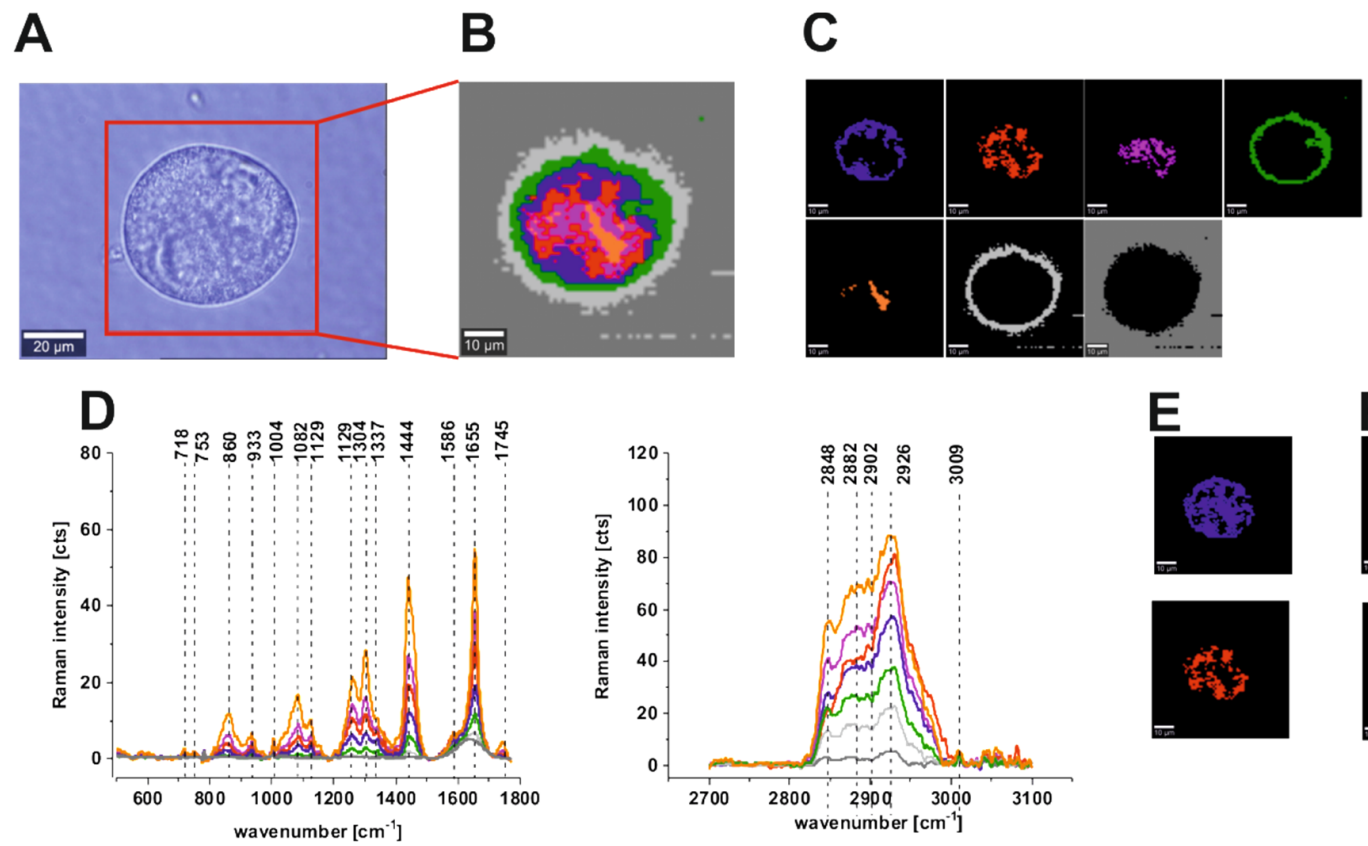

F
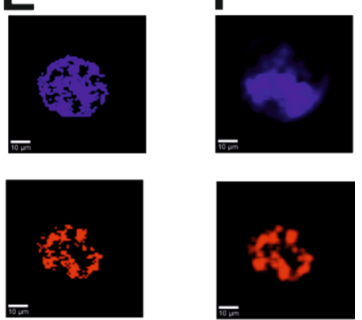

Figure 8. Microscopy image (A), Raman image constructed based on CA method (B), Raman images of all clusters identified by CA, nucleus (red), mitochondria (magenta), lipid-rich regions (blue and orange), membrane (light gray), cytoplasm (green), cell environment (dark gray) (C), Raman spectra typical of all clusters for the low- and high-frequency regions (D), Raman clusters typical of all lipid-rich structures (blue), nucleus (red) (E) and fluorescence staining (F) obtained using Red Oil-O to visualize lipid-rich regions, including lipid droplets (blue) and Hoechst 33342 to visualize nucleus (red) for CaCo-2 human colon cancer cells. The colors of the spectra correspond to the colors of the clusters.

A
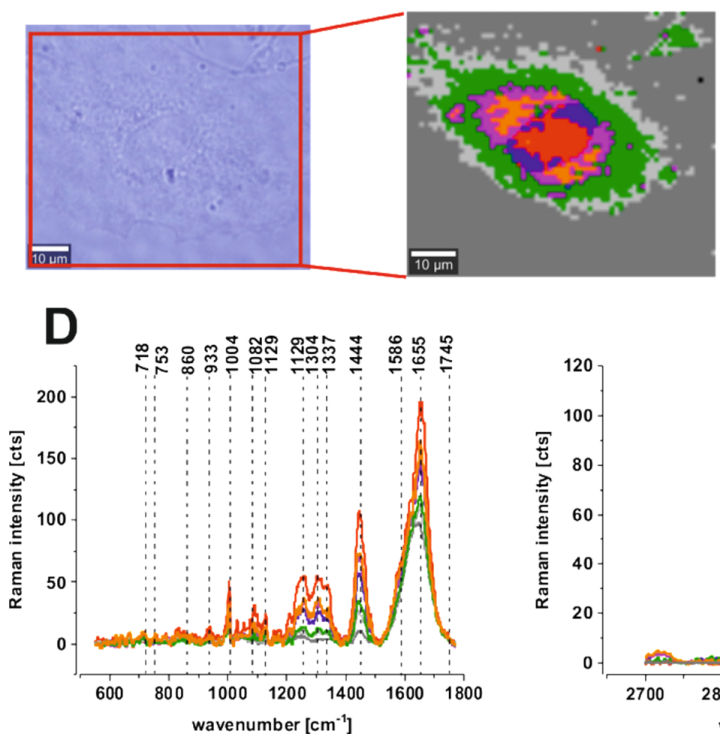

C

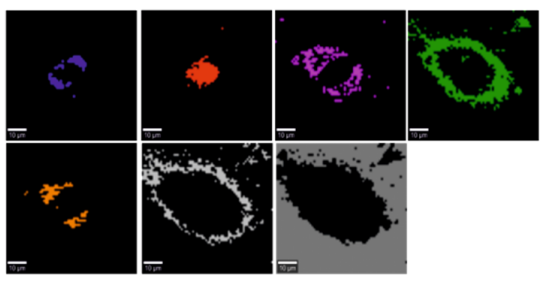

E
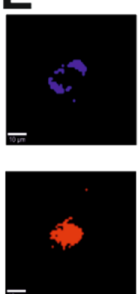

F
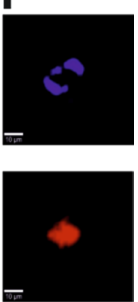

Figure 9. Microscopy image (A), Raman image constructed based on CA method (B), Raman images of all clusters identified by CA, nucleus (red), mitochondria (magenta), lipid-rich regions (blue and orange), membrane (light gray), cytoplasm (green), cell environment (dark gray) (C), Raman spectra typical of all clusters for low- and high-frequency regions (D), Raman clusters typical of all lipid-rich structures (blue), nucleus (red) (E), and fluorescence staining (F) obtained using Red Oil-O to visualize lipid-rich regions including lipid droplets (blue) and Hoechst 33342 to visualize nucleus (red) for CCD18-Co normal human colon cells. The colors of the spectra correspond to the colors of the clusters. 
One can see from Figures 8 and 9 that Raman imaging provides well-resolved Raman spectra of single colon cells, enabling the characterization of many cell organelles such as the nucleus, mitochondria, lipid-rich regions including lipid droplets, membrane, and cytoplasm. Moreover, Figures $8 \mathrm{~F}$ and $9 \mathrm{~F}$ confirm that fluorescence imaging accurately corresponds to the Raman imaging of the nucleus and lipid-rich regions for both normal and cancerous human colon cells, which helps with spectroscopic data interpretation and the correct assignment of different clusters to organelles. For the average spectra of normal and cancer cells, we calculated the difference spectrum, which is presented in Figure 10.

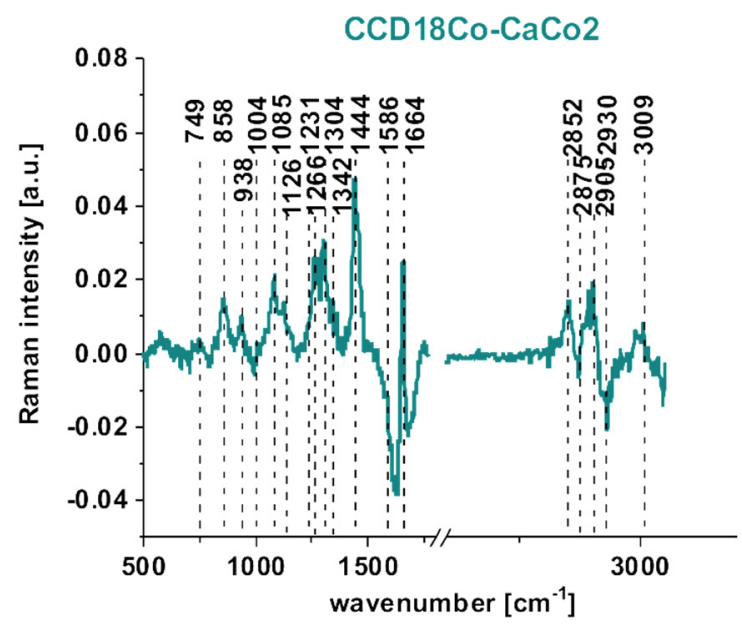

Figure 10. The difference spectrum calculated for normal human colon CCD18-Co and cancerous CaCo-2 cell lines.

The Amide III (1230-1300 $\left.\mathrm{cm}^{-1}\right)$ and Amide I bands (1600-1690 $\left.\mathrm{cm}^{-1}\right)$ are widely used to study the secondary structure of proteins and the' global amount of protein [29,39]. One can see from Figure 10 that these peaks are positive on the difference spectrum, which confirms the higher contribution of proteins for the cancerous $\mathrm{CaCo}-2$ cell line; the other protein-related bands observed at 1004,1585 , and $2926 \mathrm{~cm}^{-1}$ also are more intense in the cancerous cells. The higher content of proteins in the cancerous $\mathrm{CaCo}-2$ cell line can be explained by the fact that cancer cells typically have higher RNA/DNA content and an increasing number of studies demonstrate, e.g., the potential use of cell-free DNA as a surrogate marker for multiple indications in cancer, including diagnosis, prognosis, and monitoring $[63,64]$. The same trend can be observed for the band $858 \mathrm{~cm}^{-1}$, assigned to hydroxyproline [57]. All bands associated with the phosphates, ca. 749, 1085, $1586 \mathrm{~cm}^{-1}$, also show a higher contribution to the cancer $\mathrm{CaCo}-2$ cell line. The higher phosphorylation status of cancerous tissues has been shown in the literature for many organs including the breast, brain, and colon [57]. In contrast, a negative correlation for the cancerous CaCo-2 colon line can be observed in Figure 10 for lipid peaks from the high-frequency region $\left(2845 \mathrm{~cm}^{-1}\right)$, which confirms the reprogramming of lipids' metabolism in cancer cells [65].

To summarize, chemical differences were found between normal CCD18-Co and cancerous CaCo-2 human colon lines, based on vibrational features, for several chemical constituents: DNA/RNA, lipids, and proteins. The Raman imaging results confirm that vibrational spectra can be used to visualize many organelles of single cells, including the nucleus, cell membrane, lipid structures, mitochondria, and cytoplasm, based on the Cluster Analysis method. Moreover, we show that the Raman imaging results accurately correspond to the fluorescence imaging data, confirming the possibility of analyzing the cells' substructures without adding external dyes. 


\subsection{Human Colon Cells After Adding $\mathrm{ZnPcS}_{4}$}

Raman spectroscopy and imaging were also used to investigate the localization and photochemistry of $\mathrm{ZnPcS}_{4}$ phthalocyanine in normal and cancerous human colon single cells.

Figure 11 presents the Raman imaging data obtained after adding $\mathrm{ZnPcS}_{4}$ phthalocyanine for a final concentration in cells of $\mathrm{c}=1 \times 10^{-6} \mathrm{M}$ for the CCD-18Co and CaCo-2 human colon cell lines.



Figure 11. Microscopy image (A), Raman image constructed based on CA method and Raman images of all clusters identified by CA, nucleus (red), mitochondria (magenta), lipid-rich regions (blue and orange), membrane (light gray), cytoplasm (green), cell environment (dark gray) (B), Raman spectra typical of all clusters for low- and high-frequency regions (C), Raman image of $\mathrm{ZnPcS}_{4}$ phthalocyanine distribution based on filter $3700-4630 \mathrm{~cm}^{-1}$ (D), Raman image of the distribution of lipids structures and mitochondria based on filter $2820-2870 \mathrm{~cm}^{-1}$, (E) overlay of $\mathrm{ZnPcS}_{4}$ phthalocyanine, and mitochondria/lipids distribution filters, $(\mathbf{F})$ the concentration of $\mathrm{ZnPcS}_{4}$ in a medium $\mathrm{c}=1 \times 10^{-6} \mathrm{M}$.

One can see from Figure 11 that, for the cell lines, after adding the photosensitizer it is still possible to characterize the vibrational features of each cell substructure such as the nucleus, lipid structures, mitochondria, membrane, and cytoplasm (panel B). Moreover, based on the Raman spectra (panel C), it is possible to identify DNA/RNA, proteins, phosphorylated proteins, lipids, and unsaturated lipid signals. However, in this experiment, we mostly focused on the localization of the phthalocyanine inside each cell. One can see from Figure 11 that, based on the Raman imaging data and filters typical of mitochondria and lipids $\left(2820-2870 \mathrm{~cm}^{-1}\right)$ in panel $\mathrm{E}$ and the Raman/fluorescence signals of $\mathrm{ZnPcS}_{4}$ (3700-4630 $\mathrm{cm}^{-1}$ ) in panel $\mathrm{D}$, a perfect match is observed between the localization of mitochondria, lipids structures, and phthalocyanine inside cells. Moreover, this observation is true for both the normal CCD18-Co and cancerous CaCo2-Co human colon cells. This finding is confirmed by Figure 11F, which shows the overlay of mitochondria/lipids and phthalocyanine filters. 
To check if the $\mathrm{ZnPcS}_{4}$ concentration can affect the localization of the photosensitizer inside cells, we performed the same experiments for the higher concentration of $\mathrm{ZnPcS}_{4}\left(\mathrm{c}=9 \times 10^{-6} \mathrm{M}\right)$. Figure 12 shows the results obtained for human normal and cancerous colon cells CCD18-Co and CaCo-2, respectively.
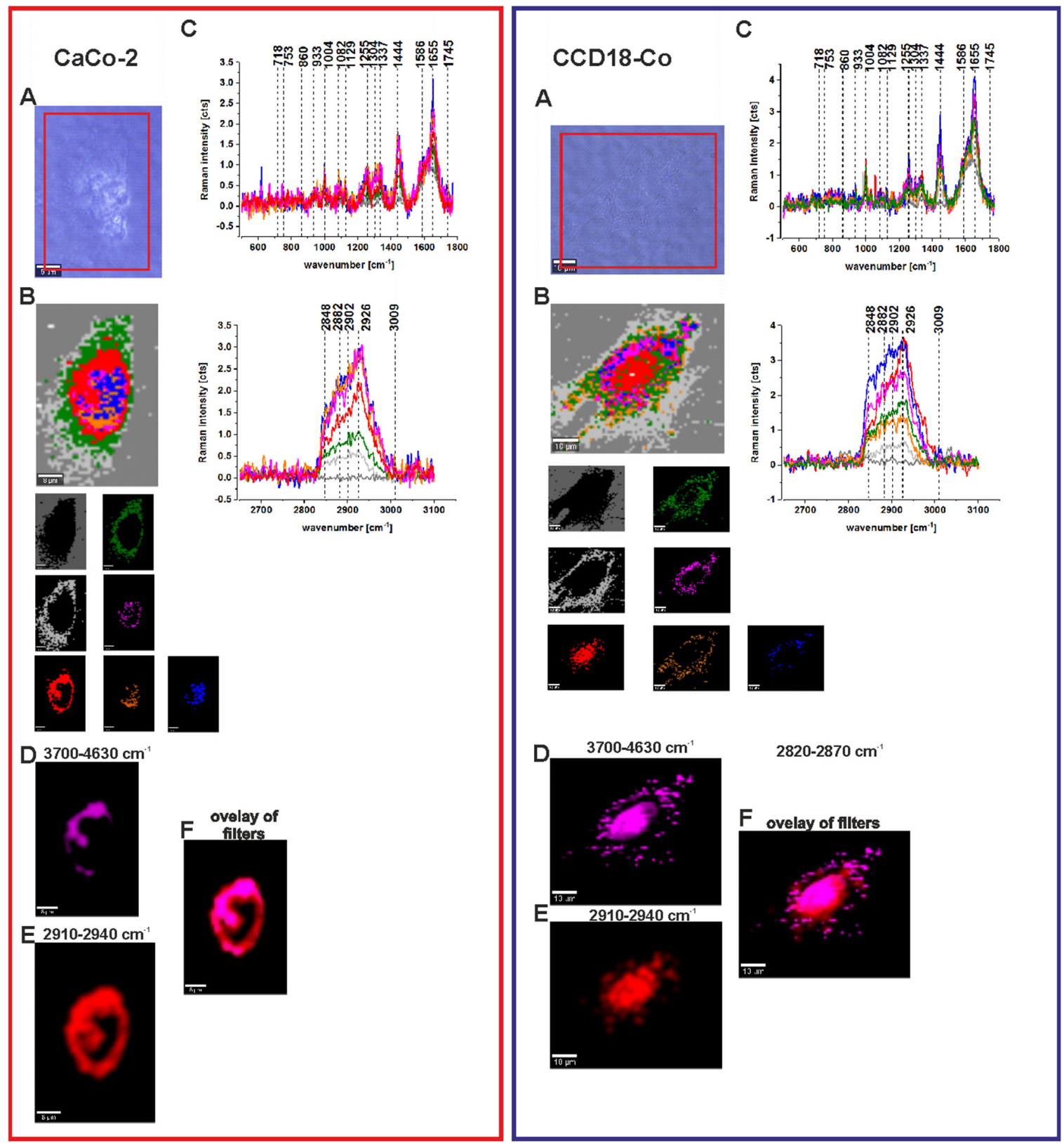

Figure 12. Microscopy image (A), Raman image constructed based on CA method and Raman images of all clusters identified by CA, nucleus (red), mitochondria (magenta), lipid-rich regions (blue and orange), membrane (light gray), cytoplasm (green), cell environment (dark gray) (B), Raman spectra typical of all clusters for low- and high-frequency regions (C), Raman image of $\mathrm{ZnPcS}_{4}$ phthalocyanine distribution based on filter $3700-4630 \mathrm{~cm}^{-1}$ (D), Raman image of the nucleus based on filter $2910-2940 \mathrm{~cm}^{-1}$, (E) overlay of $\mathrm{ZnPcS}_{4}$ phthalocyanine, and nucleus distribution filters, (F) the concentration of $\mathrm{ZnPcS}_{4}$ in a medium $\mathrm{c}=9 \times 10^{-6} \mathrm{M}$.

Once again, one can see from Figure 12 that adding the photosensitizer does not disturb the vibrational features of normal and cancerous human colon cells (panel C), but the most important finding of this experiment is that, for the higher concentration of $\mathrm{ZnPcS}_{4}$, the localization of the 
photosensitizer (panel D) is different and the localization inside the nucleus is predominant (panels E and F). As for the lower concentration, this conclusion was true for both normal and cancerous human colon cells (CCD18-Co and CaCo-2 respectively).

To summarize, for normal and cancerous human colon cells, we proved that the localization of $\mathrm{ZnPcS}_{4}$ is concentration-dependent and so different mechanisms of cell death should be taken into account.

In PDT, an appropriate Pcs should be capable of inducing efficient formation of ROS after irradiation. Because ROS formation is a local effect, due to their short life-time and minimal radius of action, knowledge about the localization of the photosensitizer is crucial to the understanding of the mechanisms of programming cell death. It has been shown that many factors affect the complexity of the localization process, such as the central atom, substituents present in the macrocycle, and cell type (including cancer type and stage) [65]. Moreover, it has been proven that cellular uptake is a time- and concentration-dependent process [66]. This is why all of the studies regarding the PC localization are so important for future PDT development. Our results represent, therefore, another voice contributing to this lively discussion.

In our experiments, we show that, for the low $\mathrm{ZnPcS}_{4}$ phthalocyanine concentration $\left(c=1 \times 10^{-6} \mathrm{M}\right)$, the localization of the photosensitizer applies to mitochondria and lipid structures. This finding is consistent with the results proving that mono- or polysubstituted ZnPcs are mainly localized in the mitochondria and/or lysosomes in the Golgi apparatus, and, at a lower concentration, in the endoplasmic reticulum (ER) [67-74].

The mitochondrial-targeted PDT using ZnPcs was investigated by Muli et al. and Lan et al. [70,71].

It is well known also that mitochondrial homeostasis is essential for cell viability. This is why the mechanisms involving PDT damage to this organelle including caspase activation, deregulation in the expression of Bcl-2 family proteins, and reduction of mitochondria membrane potential are so interesting and have been reported in the literature after ZnPcs PDT [72,75].

Although the role of ER as a Pcs location is not clear, we have to remember that the ER is a key organelle involved in the folding and trafficking of newly synthesized proteins as well as in the maintenance of $\mathrm{Ca}^{2}+$ homeostasis, which is why ER photodamage after PDT can contribute to apoptotic cell death. An increase in the intracellular $\mathrm{Ca}^{2}+$ concentration and higher expression levels of ER stress marker proteins were reported after PDT treatment by using ZnPcs [76].

For the higher $\mathrm{ZnPcS} 4$ phthalocyanine concentration, we proved the preferential localization in the nucleus, which is the most important organelle. These results are in agreement with the data obtained by Kuzyniak et al. [77] and Machado et al. [78].

The nucleus is the largest cellular organelle, storing genetic information in the form of DNA. Singlet oxygen generated during PDT treatment is able to react with DNA by inducing guanine-to-thymine transversions due to 8-oxo-7,8-dihydro-20-deoxyguanosine generation. Nucleotide excision repair, base excision repair, and mismatch repair are implicated in the correction of DNA lesions induced by ${ }^{1} \mathrm{O}_{2}$. At the molecular level, ${ }^{1} \mathrm{O}_{2}$ is also able to induce the expression of genes involved in the cellular response to oxidative stress, such as NF-kB (nuclear factor kappa-light-chain-enhancer of activated B cells), c-fos (proto-oncogene), and c-jun (protein encoded by the JUN gene), and genes involved in tissue damage and inflammation such as ICAM-1 and interleukins 1 and 6. DNA-PDT damage-controlled cell death can be observed, e.g., as a result of nuclear condensation and DNA fragmentation during apoptosis. The most-studied pathway involves the nuclear translocation of apoptosis-inducing factor [79-81].

\subsection{Transient Absorption}

The impact of biological interfaces such as normal and cancerous colon tissues and cells on excited state lifetime of $\mathrm{ZnPcS} 4$ was investigated by means of transient absorption spectroscopy. Figure 13 shows the transient absorption kinetic traces of $\mathrm{ZnPcS}_{4}$ film on $\mathrm{CaF}_{2}$ substrate (green line), CaCo-2 cells incubated with $\mathrm{ZnPcS}_{4}$ at $\mathrm{c}=1 \times 10^{-4} \mathrm{M}$ (violet line), CCD18-Co cells incubated with 
$\mathrm{ZnPcS}_{4}$ at $\mathrm{c}=1 \times 10^{-4} \mathrm{M}$ (turquoise line), normal colon tissue soaked with an aqueous $\mathrm{ZnPcS}_{4}$ solution at $c=1 \times 10^{-4} \mathrm{M}$ (blue line), cancerous colon tissue soaked with an aqueous $\mathrm{ZnPcS}_{4}$ solution at $\mathrm{c}=1 \times 10^{-4} \mathrm{M}$ (red line) for pump and probe wavelength $650 \mathrm{~nm}(200 \mathrm{~nJ})$ and $570 \mathrm{~nm}$ $(15 \mathrm{~nJ})$, respectively.



Figure 13. The transient absorption kinetic traces of $\mathrm{ZnPcS}_{4}$ film on $\mathrm{CaF}_{2}$ substrate (green line), CaCo-2 cells incubated with $\mathrm{ZnPcS}_{4}$ at c $=1 \times 10^{-4} \mathrm{M}$ (violet line), CCD18-Co cells incubated with $\mathrm{ZnPcS}_{4}$ at $\mathrm{c}=1 \times 10^{-4} \mathrm{M}$ (turquoise line), normal colon tissue soaked with an aqueous $\mathrm{ZnPcS}_{4}$ solution at $\mathrm{c}=1 \times 10^{-4} \mathrm{M}$ (blue line), cancerous colon tissue soaked with an aqueous solution at $\mathrm{c}=1 \times 10^{-4} \mathrm{M}$ (red line). Pump and probe wavelength and energies were $650 \mathrm{~nm}$ (200 nJ) and $570 \mathrm{~nm}$ (15 nJ), respectively.

ROS form as a result of reactions of the long-lived triplet state of the sensitizer with biomolecules in the presence of oxygen (type I reactions), or directly with oxygen in its ground triplet state (type II reactions). Therefore, the long excited-state lifetime of the photosensitizer is expected to favor photosensing efficiency. As the excited state lifetime depends on the surrounding of the chromophore, studying lifetimes in environments such as cells or tissues helps us to assess the potential effectiveness of the photosensitizer in vivo. For this reason, we measured the transient absorption of cancerous (CaCo-2) and normal (CCD18-Co) cells incubated with $\mathrm{ZnPcS}_{4}$, and cancerous and normal colon tissues soaked with an aqueous solution of $\mathrm{ZnPcS}_{4}$. We compared the kinetic traces of $\mathrm{ZnPcS}_{4}$ in biological environments with those of $\mathrm{ZnPcS}_{4}$ film on a bare $\mathrm{CaF}_{2}$ substrate (see Figure 13). The positive $\Delta \mathrm{A}$ signals observed for all decay curves arise mainly from the excited state absorption because the probe at $570 \mathrm{~nm}$ covers only the edge of the ground state absorption spectrum of $\mathrm{ZnPcS}_{4}$ (see Figure 1). However, ground state bleaching also participates in the $\Delta \mathrm{A}$ signal, reducing the absolute value of the $\Delta \mathrm{A}$. The decay of $\Delta \mathrm{A}$ signal at $570 \mathrm{~nm}$ was three exponential and fitted with time constants varying from single ps to hundreds of ps. Table 2 shows the relaxation time constants for $\mathrm{ZnPcS}_{4}$ phthalocyanine obtained in our experiments.

One can see from Table 2 that the shorter time constant varies from 3.0 ps for 4.4 ps. Longer time constants of 424 and 432 ps were determined for cancerous cells and tissue, respectively. For cells and tissues, the determined lifetimes are $4.4 \pm 3.1 \mathrm{ps}, 65 \pm 32 \mathrm{ps}$, and $424 \pm 138$ ps for CaCo-2 cancer cells; $3.0 \pm 2.5$ ps, $70 \pm 32$ ps, and $340 \pm 89$ ps for CCD18-Co normal cells; $3.6 \pm 0.25$ ps, $74.0 \pm 9.0 \mathrm{ps}$, and $432.0 \pm 98$ ps for cancerous human colon tissue; and $3.0 \pm 0.25$ ps, $53.5 \pm 5.7 \mathrm{ps}$, and $346.0 \pm 38$ ps for normal human colon tissue. The relative amplitudes of the determined time constants are also presented in Table 2. The longest time constant observed for samples of tissues and cells should be assigned to the excited single state $\left(S_{1}\right)$ lifetime of the photosensitizer. In contrast, for the 
aqueous solution, the long-time constant of few hundred ps is not observed due to fast $S_{1} \rightarrow S_{0}$ internal conversion occurring in aggregates of $\mathrm{ZnPcS}_{4}$ [14,54]. While we are not able to measure the triplet state lifetime due to limited length of our delay stage, the increase $S_{1}$ state lifetime should lead to higher yield of triplet state formation. The observed elongation of excited state lifetime is similar to that observed for $\mathrm{ZnPcS}_{4}$ monomers in micelles and in DMSO [14,54]. The most probable explanation of this behavior is disaggregation caused by interactions between $\mathrm{ZnPcS}_{4}$ molecules and biological interfaces. This mechanism is supported by the presence of observable fluorescence presumably having contribution from both $\mathrm{ZnPcS}_{4}$ monomers and non-cofacial aggregates (Figures $6 \mathrm{C}$ and $7 \mathrm{C}$ ). If this is the case, then the smaller amount of aggregates should facilitate interactions between the triplet state of photosensitizer and molecular oxygen as aggregates are more difficult to be penetrated by oxygen. The increase of S1 lifetime due to presence of $\mathrm{ZnPcS} 4$ monomers at biological interfaces should lead to rise of quantum yield of $\mathrm{T} 1$ because of less efficient $\mathrm{S} 1 \rightarrow \mathrm{S} 0$ internal conversion which is a competitive process for intersystem crossing $\mathrm{S} 1 \rightarrow \mathrm{T} 1$. The relative amplitude of the longest time constant assigned to the S1 lifetime varies from $38 \%$ to $65 \%$ for all $\mathrm{ZnPcS} 4$ at biological interfaces. This means that the value of triplet state quantum yield for $\mathrm{ZnPcS} 4$ at biological interfaces can be estimated to vary from $0.38 \times 0.3$ to $0.65 \times 0.3$ where 0.3 is reported value for ZnPcS4 in disaggregating solvent-DMF [82] The value of triplet state quantum yield formation for $\mathrm{ZnPcS4}$ at biological interfaces is expected to be much higher than that for pure aggregates in which very efficient internal conversion occurs. Apart from the a few hundred picosecond time constant assigned to S1 state of ZnPcS4 monomer, we observe two shorter time constants. The time constant in the range of 30-75 ps we assign to vibrational cooling. The time constants in the range of 3-5 ps may arise from internal conversion of aggregates. The observations presented for biological samples are in agreement with those made for human breast tissues by Abramczyk et al. [52,53,83].

Table 2. Relaxation time constants for ZnPcS4 phthalocyanine. The relative amplitudes for time constants are given in parentheses.

\begin{tabular}{cc}
\hline Sample & Time Constants \\
\hline $\mathrm{ZnPcS}_{4}$ film on $\mathrm{CaF}_{2}$ & $3.97 \pm 1.2 \mathrm{ps}(28 \%), 32.3 \pm 6.3 \mathrm{ps}(44 \%), 190 \mathrm{ps} \pm 46(28 \%)$ \\
\hline $\mathrm{CaCo}-2$ cells incubated with $\mathrm{ZnPcS}_{4}$ & $4.4 \pm 3.1 \mathrm{ps}(7 \%), 65 \pm 32 \mathrm{ps}(28 \%), 424 \pm 138 \mathrm{ps}(65 \%)$ \\
\hline CCD18-Co cells incubated with $\mathrm{ZnPcS}_{4}$ & $3.0 \pm 2.5 \mathrm{ps}(7 \%), 70 \pm 32 \mathrm{ps}(31 \%), 340 \pm 89 \mathrm{ps}(62 \%)$ \\
\hline Cancerous colon tissue soaked with $\mathrm{ZnPcS}_{4}$ solution & $3.6 \pm 0.25 \mathrm{ps}(25 \%), 74.0 \pm 9.0 \mathrm{ps}(37 \%), 432.0 \pm 98 \mathrm{ps}(38 \%)$ \\
\hline Normal colon tissue soaked with $\mathrm{ZnPcS}_{4}$ solution & $3.0 \pm 0.25 \mathrm{ps}(21 \%), 53.5 \pm 5.7 \mathrm{ps}(36 \%), 346.0 \pm 38 \mathrm{ps}(43 \%)$ \\
\hline
\end{tabular}

To summarize, the presence of biological interfaces leads to an elongation of the excited state lifetime, which is beneficial for application in PDT, and the biological environment plays a crucial role in energy dissipation mechanisms in biological systems.

\section{Conclusions}

Raman imaging and spectroscopy were successfully used to characterize and differentiate normal and cancerous human colon tissues and cell lines based on vibrational features. Moreover, substructures of human colon single cells such as the nucleus, mitochondria lipid-rich regions, membrane, and cytoplasm can be precisely visualized based on the Raman spectra. Detailed biochemical information on human tissue samples can be obtained using Raman imaging for human colon tissues and cells without and after adding the $\mathrm{ZnPcS}_{4}$ photosensitizer. Fluorescence-based images accurately correspond to the Raman images, confirming the location of nucleus and lipid-rich structures. Based on Raman/fluorescence spectra and the images we obtained, we gleaned new information about the photosensitizer localization, concentration, and aggregation in normal and cancerous human colon tissues and cells. For normal human colon tissue samples, in contrast to cancerous ones, we observed lower affinity to $\mathrm{ZnPcS}_{4}$ phthalocyanine and the lower Raman/fluorescence signals typical of $\mathrm{ZnPcS}_{4}$. 
The higher concentration in cancerous tissue was concomitant with a blue-shift of the maximum peak position of the photosensitizer ( $689 \mathrm{~nm}$ for cancerous tissue and 691-695 nm for normal tissue; excitation wavelength: $532 \mathrm{~nm}$ ). For both types of samples, the signal was observed in the monomer region, confirming the excellent properties of $\mathrm{ZnPcS}_{4}$ for PDTF. For colon cells, in experiments with a low concentration of $\mathrm{ZnPcS}_{4}$ photosensitizer $\left(\mathrm{c}=1 \times 10^{-6} \mathrm{M}\right)$, the phthalocyanine was located in the mitochondria/lipid structures; for the higher concentration $\left(c=9 \times 10^{-6} \mathrm{M}\right)$, localization inside the nucleus was predominant. $\mathrm{ZnPcS}_{4}$ in the presence of biological interfaces is characterized by longer excited state lifetimes in comparison to aqueous solutions and bare $\mathrm{ZnPcS}_{4}$ films on $\mathrm{CaF}_{2}$ substrates. This finding is beneficial for the application of $\mathrm{ZnPcS}_{4}$ in PDT, and indicates that the biological environment plays a crucial role in energy dissipation mechanisms.

Author Contributions: H.A.: Conceptualization, Raman and fluorescence data analysis, femtosecond spectroscopy data analysis, manuscript editing. B.B.-P.: Conceptualization, Raman and fluorescence data measurements, Raman, fluorescence and femtosecond spectroscopy data analysis, original draft preparation, reviewing and manuscript editing. A.J.: Femtosecond spectroscopy data measurements and analysis, reviewing and manuscript editing. R.K.: Femtosecond spectroscopy data measurements and analysis. All authors have read and agreed to the published version of the manuscript.

Funding: This project was funded through the National Science Centre Poland Grant UMO-2017/25/B/ST4/01788.

Acknowledgments: The authors would like to thank A.K. Olejnik from the Institute of Applied Radiation Chemistry, Lodz University of Technology, Lodz, Poland for human colon cell lines culturing.

Conflicts of Interest: The authors declare no competing interests.

\section{References}

1. Lu, G.; Yan, S.; Shi, M.; Yu, W.; Li, J.; Zhu, W.; Ou, Z.; Kadish, K.M. A new class of rare earth tetrapyrrole sandwich complexes containing corrole and phthalocyanine macrocycles: Synthesis, physicochemical characterization and X-ray analysis. Chem. Commun. 2015, 51, 2411-2413. [CrossRef] [PubMed]

2. Abramczyk, H.; Szymczyk, I.; Waliszewska, G.; Lebioda, A. Photoinduced Redox Processes in Phthalocyanine Derivatives by Resonance Raman Spectroscopy. J. Phys. Chem. A 2004, 108, 264-274. [CrossRef]

3. Abramczyk, H.; Szymczyk, I. Novel Approaches to the Structure and Dynamics of Liquids: Experiments, Theories and Simulations; Springer Science \& Business Media: Heidelberg, Germany, 2013; ISBN 978-1-4020-2384-2.

4. Szymczyk, I.; Abramczyk, H. Peripheral substituent and solvent effects on the aggregation and photochemical properties of copper(II)phthalocyanine and copper(II)phthalocyanine-3,4',4",4"'-tetrasulfonic anion. Pure Appl. Chem. 2004, 76, 183-187. [CrossRef]

5. Abramczyk, H.; Szymczyk, I. Aggregation of phthalocyanine derivatives in liquid solutions and human blood. J. Mol. Liq. 2004, 110, 51-56. [CrossRef]

6. An, L.B.; Feng, L.J.; Lu, C.G. Mechanical Properties and Applications of Carbon Nanotubes. Adv. Mater. Res. 2011, 295, 1516-1521. [CrossRef]

7. Kobayashi, N.; Sirai, H. Phthalocyanines - Chemistry and Functions; IPc: Tokyo, Japan, 1997.

8. Prasad, D.R.; Ferraudi, G. Photochemistry of transition-metal phthalocyanines. Monophotonic and sequential biphotonic photochemical processes of copper(II) tetrakis(N-octadecylsulfamoyl)phthalocyanine in nonaqueous media. Inorg. Chem. 1982, 21, 2967-2971. [CrossRef]

9. Ferraudi, G.; Muralidharan, S. Photochemistry of transition-metal phthalocyanines. Analysis of the photochemical and photophysical properties of the acido(phthalocyaninato)rhodium(III) complexes. Inorg. Chem. 1983, 22, 1369-1374. [CrossRef]

10. Muralidharan, S.; Ferraudi, G. Sequential biphotonic processes in rhodium(III) phthalocyanines. J. Phys. Chem. 1983, 87, 4877-4881. [CrossRef]

11. Kaneko, Y.; Arai, T.; Sakuragi, H.; Tokumaru, K.; Pac, C. Effect of excitation wavelength on photoreduction of metal-free and copper(II) 1,4,8,11,15,18,22,25-octabutoxyphthalocyanines with triethanolamine. J. Photochem. Photobiol. A Chem. 1996, 97, 155-162. [CrossRef] 
12. Kaneko, Y.; Nishimura, Y.; Arai, T.; Sakuragi, H.; Tokumaru, K.; Matsunaga, D. UV light and red light chemistry of metallophthalocyanine: Wavelength-dependent photochemical reduction of tetrasodium salts of $\mathrm{Zn}(\mathrm{II})$ and $\mathrm{Cu}(\mathrm{II})$ tetrasulphonatophthalocyanines with amines. J. Photochem. Photobiol. A Chem. 1995, 89, 37-44. [CrossRef]

13. Kaneko, Y.; Nishimura, Y.; Takane, N.; Arai, T.; Sakuragi, H.; Kobayashi, N.; Matsunaga, D.; Pac, C.; Tokumaru, K. Violet emission observed from phthalocyanines. J. Photochem. Photobiol. A Chem. 1997, 106, 177-183. [CrossRef]

14. Howe, L.; Zhang, J.Z. Ultrafast Studies of Excited-State Dynamics of Phthalocyanine and Zinc Phthalocyanine Tetrasulfonate in Solution. J. Phys. Chem. A 1997, 101, 3207-3213. [CrossRef]

15. RuUckmann, I.; Zeug, A.; Herter, R.; Röder, B. On the Influence of Higher Excited States on the ISC Quantum Yield of Octa-aL-alkyloxy-substituted Zn-Phthalocyanine Molecules Studied by Nonlinear Absorption. Photochem. Photobiol. 1997, 66, 576-584. [CrossRef]

16. Chahraoui, D.; Valat, P.; Kossanyi, J. Fluorescence of phthalocyanines: Emission from an upper excited state. Res. Chem. Intermed. 1992, 17, 219-232. [CrossRef]

17. Ball, D.J.; Mayhew, S.; Wood, S.R.; Griffiths, J.; Vernon, D.I.; Brown, S.B. A Comparative Study of the Cellular Uptake and Photodynamic Efficacy of Three Novel Zinc Phthalocyanines of Differing Charge. Photochem. Photobiol. 2008, 69, 390-396. [CrossRef]

18. Kobayashi, N.; Lever, A.B.P. Cation or solvent-induced supermolecular phthalocyanine formation: Crown ether substituted phthalocyanines. J. Am. Chem. Soc. 1987, 109, 7433-7441. [CrossRef]

19. Kobayashi, N.; Lam, H.; Nevin, W.A.; Janda, P.; Leznoff, C.C.; Koyama, T.; Monden, A.; Shirai, H. Synthesis, spectroscopy, electrochemistry, spectroelectrochemistry, Langmuir-Blodgett film formation, and molecular orbital calculations of planar binuclear phthalocyanines. J. Am. Chem. Soc. 1994, 116, 879-890. [CrossRef]

20. Kobayashi, N.; Togashi, M.; Osa, T.; Ishii, K.; Yamauchi, S.; Hino, H. Low Symmetrical Phthalocyanine Analogues Substituted with Three Crown Ether Voids and Their Cation-Induced Supermolecules. J. Am. Chem. Soc. 1996, 118, 1073-1085. [CrossRef]

21. Lagorio, M.G.; Dicelio, L.E.; Roman, E.S. Visible and near-IR spectroscopic and photochemical characterization of substituted metallophthalocyanines. J. Photochem. Photobiol. A Chem. 1993, 72, 153-161. [CrossRef]

22. Marino, J.; Vior, M.C.G.; Dicelio, L.E.; Roguin, L.P.; Awruch, J. Photodynamic effects of isosteric water-soluble phthalocyanines on human nasopharynx KB carcinoma cells. Eur. J. Med. Chem. 2010, 45, 4129-4139. [CrossRef] [PubMed]

23. Jori, G. Far-red-absorbing photosensitizers: Their use in the photodynamic therapy of tumours. J. Photochem. Photobiol. A Chem. 1992, 62, 371-378. [CrossRef]

24. Kuznetsova, N.A.; Gretsova, N.S.; Derkacheva, V.M.; Kaliya, O.L.; Lukyanets, E.A. Sulfonated phthalocyanines: Aggregation and singlet oxygen quantum yield in aqueous solutions. J. Porphyrins Phthalocyanines 2003, 7, 147-154. [CrossRef]

25. Wang, S.; Gao, R.; Zhou, F.; Selke, M. Nanomaterials and singlet oxygen photosensitizers: Potential applications in photodynamic therapy. J. Mater. Chem. 2004, 14, 487. [CrossRef]

26. Zhang, Y.; Lovell, J.F. Recent Applications of Phthalocyanines and Naphthalocyanines for Imaging and Therapy. Wiley Interdiscip. Rev. Nanomed. Nanobiotechnol. 2016, 9, e1420. [CrossRef] [PubMed]

27. Brown, S.B.; A Brown, E.; Walker, I. The present and future role of photodynamic therapy in cancer treatment. Lancet Oncol. 2004, 5, 497-508. [CrossRef]

28. Zhang, J.; Fan, Y.; He, M.; Ma, X.; Song, Y.; Liu, M.; Xu, J. Accuracy of Raman spectroscopy in differentiating brain tumor from normal brain tissue. Oncotarget 2017, 8, 36824-36831. [CrossRef] [PubMed]

29. Kalkanis, S.N.; Kast, R.; Rosenblum, M.L.; Mikkelsen, T.; Yurgelevic, S.M.; Nelson, K.M.; Raghunathan, A.; Poisson, L.M.; Auner, G.W. Raman spectroscopy to distinguish grey matter, necrosis, and glioblastoma multiforme in frozen tissue sections. J. Neuro Oncol. 2014, 116, 477-485. [CrossRef] [PubMed]

30. Hollon, T.; Lewis, S.; Freudiger, C.W.; Xie, X.S.; Orringer, D.A. Improving the accuracy of brain tumor surgery via Raman-based technology. Neurosurg. Focus 2016, 40, E9. [CrossRef] [PubMed]

31. Anna, I.; Bartosz, P.; Lech, P.; Halina, A. Novel strategies of Raman imaging for brain tumor research. Oncotarget 2017, 8, 85290-85310. [CrossRef] [PubMed]

32. Abramczyk, H.; Brozek-Pluska, B.; Surmacki, J.M.; Jablonska-Gajewicz, J.; Kordek, R. Raman 'optical biopsy' of human breast cancer. Prog. Biophys. Mol. Boil. 2012, 108, 74-81. [CrossRef] [PubMed] 
33. Li, Q.; Gao, Q.; Zhang, G. Classification for breast cancer diagnosis with Raman spectroscopy. Biomed. Opt. Express 2014, 5, 2435-2445. [CrossRef] [PubMed]

34. Li, Q.; Hao, C.; Xu, Z. Diagnosis of Breast Cancer Tissues Using $785 \mathrm{~nm}$ Miniature Raman Spectrometer and Pattern Regression. Sensors 2017, 17, 627. [CrossRef] [PubMed]

35. Abramczyk, H.; Brozek-Pluska, B. Apical-basal polarity of epithelial cells imaged by Raman microscopy and Raman imaging: Capabilities and challenges for cancer research. J. Mol. Liq. 2017, 245, 52-61. [CrossRef]

36. Brozek-Pluska, B.; Kopeć, M.; Abramczyk, H. Development of a new diagnostic Raman method for monitoring epigenetic modifications in the cancer cells of human breast tissue. Anal. Methods 2016, 8, 8542-8553. [CrossRef]

37. Surmacki, J.M.; Brozek-Pluska, B.; Kordek, R.; Abramczyk, H. The lipid-reactive oxygen species phenotype of breast cancer. Raman spectroscopy and mapping, PCA and PLSDA for invasive ductal carcinoma and invasive lobular carcinoma. Molecular tumorigenic mechanisms beyond Warburg effect. Analyst 2015, 140, 2121-2133. [CrossRef] [PubMed]

38. Ishigaki, M.; Maeda, Y.; Taketani, A.; Andriana, B.B.; Ishihara, R.; Wongravee, K.; Ozaki, Y.; Sato, H. Diagnosis of early-stage esophageal cancer by Raman spectroscopy and chemometric techniques. Analyst 2016, 141, 1027-1033. [CrossRef] [PubMed]

39. Shetty, G.; Kendall, C.; Shepherd, N.; Stone, N.; Barr, H. Raman spectroscopy: Elucidation of biochemical changes in carcinogenesis of oesophagus. Br. J. Cancer 2006, 94, 1460-1464. [CrossRef] [PubMed]

40. Teh, S.K.; Zheng, W.; Ho, K.Y.; Teh, M.; Yeoh, K.G.; Huang, Z. Diagnosis of gastric cancer using near-infrared Raman spectroscopy and classification and regression tree techniques. J. Biomed. Opt. 2008, 13, 034013. [CrossRef] [PubMed]

41. Brozek-Pluska, B.; Morawiec-Sztandera, A.; Kopeć, M.; Niedzwiecka, I. Label-free determination of lipid composition and secondary protein structure of human salivary noncancerous and cancerous tissues by Raman microspectroscopy. Analyst 2015, 140, 2107-2113. [CrossRef] [PubMed]

42. Kanter, E.M.; Majumder, S.; Vargis, E.; Robichaux-Viehoever, A.; Kanter, G.J.; Shappell, H.; Jones, H.W.; Mahadevan-Jansen, A. Multiclass discrimination of cervical precancers using Raman spectroscopy. J. Raman Spectrosc. 2009, 40, 205-211. [CrossRef] [PubMed]

43. Liu, W.; Wang, H.; Du, J.; Jing, C. Raman microspectroscopy of nucleus and cytoplasm for human colon cancer diagnosis. Biosens. Bioelectron. 2017, 97, 70-74. [CrossRef] [PubMed]

44. A Jenkins, C.; Lewis, P.D.; Dunstan, P.; A Harris, D. Role of Raman spectroscopy and surface enhanced Raman spectroscopy in colorectal cancer. World J. Gastrointest. Oncol. 2016, 8, 427-438. [CrossRef] [PubMed]

45. Park, D.; Ryu, S.; Kim, Y.-H.; Lee, C.K.; Eun, C.; Han, D.-S.; Lee, S.-H. Comparison of a Guaiac-Based and a Quantitative Immunochemical Fecal Occult Blood Testing in Average-Risk Population for Colorectal Cancer Screening. Gastrointest. Endosc. 2009, 69, AB278-AB279. [CrossRef]

46. Brozek-Pluska, B.; Miazek, K.; Musiał, J.; Kordek, R. Label-free diagnostics and cancer surgery Raman spectra guidance for the human colon at different excitation wavelengths. RSC Adv. 2019, 9, 40445-40454. [CrossRef]

47. Brozek-Pluska, B.; Orlikowski, M.; Abramczyk, H.; Kadish, K.M.; Smith, K.M.; Guilard, R. Phthalocyanines: From Dyes to Photosensitizers in Diagnostics and Treatment of Cancer. Spectroscopy and Raman Imaging Studies of Phthalocyanines in Human Breast Tissues. In Handbook of Porphyrin Science (Volumes 36-40); World Scientific Pub Co Pte Lt: Hackensack, NJ, USA, 2016; Volume 40, pp. 1-49.

48. Brozek-Pluska, B.; Jarota, A.; Kurczewski, K.; Abramczyk, H. Photochemistry of tetrasulphonated zinc phthalocyanine in water and DMSO solutions by absorption, emission, Raman spectroscopy and femtosecond transient absorption spectroscopy. J. Mol. Struct. 2009, 924, 338-346. [CrossRef]

49. Brozek-Pluska, B.; Szymczyk, I.; Abramczyk, H. Raman spectroscopy of phthalocyanines and their sulfonated derivatives. J. Mol. Struct. 2005, 744, 481-485. [CrossRef]

50. Brozek-Pluska, B.; Jarota, A.; Jablonska-Gajewicz, J.; Kordek, R.; Czajkowski, W.; Abramczyk, H. Distribution of phthalocyanines and Raman reporters in human cancerous and noncancerous breast tissue as studied by Raman imaging. Technol. Cancer Res. Treat. 2012, 11, 317-331. [CrossRef] [PubMed]

51. Abramczyk, H.; Brozek-Pluska, B.; Surmacki, J.M.; Musial, J.; Kordek, R. Oncologic photodynamic diagnosis and therapy: Confocal Raman/fluorescence imaging of metal phthalocyanines in human breast cancer tissue in vitro. Analyst 2014, 139, 5547-5559. [CrossRef] [PubMed] 
52. Abramczyk, H.; Brozek-Pluska, B.; Tondusson, M.; Freysz, E. Ultrafast Dynamics of Metal Complexes of Tetrasulfonated Phthalocyanines at Biological Interfaces: Comparison between Photochemistry in Solutions, Films, and Noncancerous and Cancerous Human Breast Tissues. J. Phys. Chem. C 2013, 117, 4999-5013. [CrossRef]

53. Jarota, A.; Tondusson, M.; Galle, G.; Freysz, E.; Abramczyk, H. Ultrafast Dynamics of Metal Complexes of Tetrasulphonated Phthalocyanines. J. Phys. Chem. A 2012, 116, 4000-4009. [CrossRef] [PubMed]

54. Howe, L.; Zhang, J.Z. The Effect of Biological Substrates on the Ultrafast Excited-state Dynamics of Zinc Phthalocyanine Tetrasulfonate in Solution. Photochem. Photobiol. 1998, 67, 90-96. [CrossRef] [PubMed]

55. Mack, J.; Stillman, M.J. Transition assignments in the ultraviolet-visible absorption and magnetic circular dichroism spectra of phthalocyanines. Inorg. Chem. 2001, 40, 812-814. [CrossRef] [PubMed]

56. Movasaghi, Z.; Rehman, S.; Rehman, I.U. Raman Spectroscopy of Biological Tissues. Appl. Spectrosc. Rev. 2007, 42, 493-541. [CrossRef]

57. Abramczyk, H.; Imiela, A.; Brozek-Pluska, B.; Kopeć, M.; Surmacki, J.M.; Sliwinska, A. Aberrant Protein Phosphorylation in Cancer by Using Raman Biomarkers. Cancers 2019, 11, 2017. [CrossRef] [PubMed]

58. Dukor, R.K. Vibrational Spectroscopy in the Detection of Cancer. In Handbook of Vibrational Spectroscopy; Wiley: Hoboken, NJ, USA, 2006.

59. Kopec, M.; Imiela, A.; Abramczyk, H. Monitoring glycosylation metabolism in brain and breast cancer by Raman imaging. Sci. Rep. 2019, 9, 166. [CrossRef] [PubMed]

60. Brozek-Pluska, B.; Musial, J.; Kordek, R.; Abramczyk, H.; Pluska, B. Analysis of Human Colon by Raman Spectroscopy and Imaging-Elucidation of Biochemical Changes in Carcinogenesis. Int. J. Mol. Sci. 2019, 20, 3398. [CrossRef] [PubMed]

61. Kasha, M. Energy Transfer Mechanisms and the Molecular Exciton Model for Molecular Aggregates. Radiat. Res. 1963, 20, 55. [CrossRef] [PubMed]

62. Ke, M.-R.; Chen, S.-F.; Peng, X.-H.; Zheng, Q.-F.; Zheng, B.-Y.; Yeh, C.-K.; Huang, J.-D. A tumor-targeted activatable phthalocyanine-tetrapeptide-doxorubicin conjugate for synergistic chemo-photodynamic therapy. Eur. J. Med. Chem. 2017, 127, 200-209. [CrossRef] [PubMed]

63. Damania, D.; Subramanian, H.; Backman, V.; Anderson, E.C.; Wong, M.H.; Mccarty, O.J.T.; Phillips, K.G. Network signatures of nuclear and cytoplasmic density alterations in a model of pre and postmetastatic colorectal cancer. J. Biomed. Opt. 2014, 19, 16016. [CrossRef] [PubMed]

64. Bronkhorst, A.J.; Ungerer, V.; Holdenrieder, S. The emerging role of cell-free DNA as a molecular marker for cancer management. Biomol. Detect. Quantif. 2019, 17, 100087. [CrossRef] [PubMed]

65. Abramczyk, H.; Imiela, A.; Śliwińska, A. Novel strategies of Raman imaging for exploring cancer lipid reprogramming. J. Mol. Liq. 2019, 274, 52-59. [CrossRef]

66. Tynga, I.; Houreld, N.N.; Abrahamse, H. The primary subcellular localization of Zinc phthalocyanine and its cellular impact on viability, proliferation and structure of breast cancer cells (MCF-7). J. Photochem. Photobiol. B Biol. 2013, 120, 171-176. [CrossRef] [PubMed]

67. Wood, S.R.; Holroyd, J.A.; Brown, S.B. The Subcellular Localization of Zn(ll) Phthalocyanines and Their Redistribution on Exposure to Light. Photochem. Photobiol. 1997, 65, 397-402. [CrossRef] [PubMed]

68. Manoto, S.L.; Houreld, N.N.; Abrahamse, H. Phototoxic effect of photodynamic therapy on lung cancer cells grown as a monolayer and three dimensional multicellular spheroids. Lasers Surg. Med. 2013, 45, 186-194. [CrossRef] [PubMed]

69. Tynga, I.; Houreld, N.N.; Abrahamse, H. Induced Cell Death Pathway Post Photodynamic Therapy Using a Metallophthalocyanine Photosensitizer in Breast Cancer Cells. Photomed. Laser Surg. 2014, 32, $205-211$. [CrossRef] [PubMed]

70. Muli, D.K.; Rajaputra, P.; You, Y.; McGrath, D.V. Asymmetric ZnPc-rhodamine B conjugates for mitochondrial targeted photodynamic therapy. Bioorg. Med. Chem. Lett. 2014, 24, 4496-4500. [CrossRef] [PubMed]

71. Lan, W.-L.; Liu, F.-R.; Ke, M.-R.; Lo, P.-C.; Fong, W.-P.; Ng, D.; Huang, J.-D. The effects of formulation and serum albumin on the in vitro photodynamic activity of zinc(II) phthalocyanines substituted with sulfonated quinolineoxy groups. Dye. Pigment. 2016, 128, 215-225. [CrossRef]

72. Shao, J.-W.; Dai, Y.; Zhao, W.; Xie, J.; Xue, J.; Ye, J.; Jia, L. Intracellular distribution and mechanisms of actions of photosensitizer Zinc(II)-phthalocyanine solubilized in Cremophor EL against human hepatocellular carcinoma HepG2 cells. Cancer Lett. 2013, 330, 49-56. [CrossRef] [PubMed] 
73. Manoto, S.L.; Sekhejane, P.R.; Houreld, N.N.; Abrahamse, H. Localization and phototoxic effect of zinc sulfophthalocyanine photosensitizer in human colon (DLD-1) and lung (A549) carcinoma cells (in vitro). Photodiagnosis Photodyn. Ther. 2012, 9, 52-59. [CrossRef] [PubMed]

74. Ongarora, B.G.; Hu, X.; Verberne-Sutton, S.D.; Garno, J.C.; Vicente, M.G.H. Syntheses and Photodynamic Activity of Pegylated Cationic Zn(II)-Phthalocyanines in HEp2 Cells. Theranostics 2012, 2, 850-870. [CrossRef] [PubMed]

75. Doustvandi, M.A.; Mohammadnejad, F.; Mansoori, B.; Mohammadi, A.; Navaeipour, F.; Baradaran, B.; Tajalli, H. The interaction between the light source dose and caspase-dependent and -independent apoptosis in human SK-MEL-3 skin cancer cells following photodynamic therapy with zinc phthalocyanine: A comparative study. J. Photochem. Photobiol. B Biol. 2017, 176, 62-68. [CrossRef] [PubMed]

76. Chiarante, N.; Vior, M.C.G.; Rey, O.; Marino, J.; Roguin, L.P. Lysosomal permeabilization and endoplasmic reticulum stress mediate the apoptotic response induced after photoactivation of a lipophilic zinc(II) phthalocyanine. Int. J. Biochem. Cell Biol. 2018, 103, 89-98. [CrossRef] [PubMed]

77. Kuzyniak, W.; Schmidt, J.; Glac, W.; Berkholz, J.; Steinemann, G.; Nitzsche, B.; Hoffmann, B.; Ermilov, E.A.; Gürek, A.G.; Ahsen, V.; et al. Novel zinc phthalocyanine as a promising photosensitizer for photodynamic treatment of esophageal cancer. Int. J. Oncol. 2017, 50, 953-963. [CrossRef] [PubMed]

78. Machado, A.H.A.; Braga, F.M.P.; Soares, C.P.; Pelisson, M.M.M.; Beltrame, M.; Da Silva, N.S. Photodynamic Therapy with a New Photosensitizing Agent. Photomed. Laser Surg. 2007, 25, 220-228. [CrossRef] [PubMed]

79. He, L.; He, X.; Lim, L.P.; De Stanchina, E.; Xuan, Z.; Liang, Y.; Xue, W.; Zender, L.; Magnus, J.; Ridzon, D.; et al. A microRNA component of the p53 tumour suppressor network. Nature 2007, 447, 1130-1134. [CrossRef] [PubMed]

80. Raver-Shapira, N.; Marciano, E.; Meiri, E.; Spector, Y.; Rosenfeld, N.; Moskovits, N.; Bentwich, Z.; Oren, M. Transcriptional Activation of miR-34a Contributes to p53-Mediated Apoptosis. Mol. Cell 2007, 26, 731-743. [CrossRef] [PubMed]

81. Candé, C.; Cecconi, F.; Dessen, P.; Kroemer, G. Apoptosis-inducing factor (AIF): Key to the conserved caspase-independent pathways of cell death? J. Cell Sci. 2002, 115, 4727-4734. [CrossRef] [PubMed]

82. Matlaba, P.M. Synthesis of Zinc Phthalocyanine Derivatives for Possible Use in Photodynamic Therapy. Masters' Thesis, Rhodes University, Grahamstown, South Africa, 2002.

83. Abramczyk, H.; Brozek-Pluska, B.; Surmacki, J.M.; Tondusson, M.; Freysz, E. Photostability of biological systems-Femtosecond dynamics of zinc tetrasulfonated phthalocyanine at cancerous and noncancerous human Breast tissues. J. Photochem. Photobiol. A Chem. 2017, 332, 10-24. [CrossRef]

Sample Availability: Samples of the compound are not available from the authors.

(C) 2020 by the authors. Licensee MDPI, Basel, Switzerland. This article is an open access article distributed under the terms and conditions of the Creative Commons Attribution (CC BY) license (http://creativecommons.org/licenses/by/4.0/). 